IZA DP No. 6914

Experimental Evidence on the Relationship between Tax Evasion Opportunities and Labor Supply

Philipp Doerrenberg

Denvil Duncan

October 2012 


\title{
Experimental Evidence on the Relationship between Tax Evasion Opportunities and Labor Supply
}

\author{
Philipp Doerrenberg \\ CGS, University of Cologne \\ and IZA \\ Denvil Duncan \\ SPEA, Indiana University \\ and IZA
}

Discussion Paper No. 6914

October 2012

IZA

P.O. Box 7240

53072 Bonn

Germany

\author{
Phone: +49-228-3894-0 \\ Fax: +49-228-3894-180 \\ E-mail: iza@iza.org
}

\begin{abstract}
Any opinions expressed here are those of the author(s) and not those of IZA. Research published in this series may include views on policy, but the institute itself takes no institutional policy positions. The IZA research network is committed to the IZA Guiding Principles of Research Integrity.

The Institute for the Study of Labor (IZA) in Bonn is a local and virtual international research center and a place of communication between science, politics and business. IZA is an independent nonprofit organization supported by Deutsche Post Foundation. The center is associated with the University of Bonn and offers a stimulating research environment through its international network, workshops and conferences, data service, project support, research visits and doctoral program. IZA engages in (i) original and internationally competitive research in all fields of labor economics, (ii) development of policy concepts, and (iii) dissemination of research results and concepts to the interested public.
\end{abstract}

IZA Discussion Papers often represent preliminary work and are circulated to encourage discussion. Citation of such a paper should account for its provisional character. A revised version may be available directly from the author. 


\title{
ABSTRACT
}

\section{Experimental Evidence on the Relationship between Tax Evasion Opportunities and Labor Supply"}

\begin{abstract}
Motivated by the observation that access to evasion opportunities is distributed heterogeneously across the labor market, this paper examines the extent to which labor supply elasticities with respect to tax rates depend on such evasion opportunities. We first discuss the channels through which access to evasion affects labor supply responses and then set up a laboratory experiment in which all participants undertake a real-effort task over several rounds. Subjects face a tax rate, which varies across rounds and are required to pay taxes on earned income. The treatment group is given the opportunity to underreport income while the control group is not. We find that participants in the treatment group have significantly larger effort responses to changes in the net-of-tax rate than participants in the control group; suggesting that both groups indeed react differently to taxes.
\end{abstract}

JEL Classification: H21, H24, H26, J22

Keywords: $\quad$ tax evasion, labor supply, taxable income, lab experiment, taxes

Corresponding author:

Philipp Doerrenberg

IZA

P.O. Box 7240

53072 Bonn

Germany

E-mail: doerrenberg@wiso.uni-koeln.de

\footnotetext{
* Large parts of this paper were developed and prepared during Philipp's research visit to the School of Public and Envioronmental Affairs (SPEA), Indiana University and Denvil's visit to the CGS, University of Cologne and IZA. We are thankful to these institutions for hosting us and pro- viding a stimulating research environment. We are grateful to David Gill and Victoria Prowse for providing their experimental real-effort task and sharing z-tree code (Gill and Prowse 2011, 2012). Financial support of the Deutsche Forschungsgemeinschaft (DFG) is gratefully acknowledged. We would like to thank Jim Alm, Mathias Dolls, Christoph Feldhaus, Daniel Hamermesh, Peter Kuhn, Andreas Peichl, Justin Ross, David Schindler, Sebastian Siegloch, Arne Weiss, and Christopher Zeppenfeld for helpful comments and suggestions. We are also grateful to Johanna Fimpel, Jan Mueller, Mark Pigors and Christian Weyand for helpful assistance during the experimental sessions.
} 


\section{Introduction}

Labor supply elasticities observed in empirical analyses are usually smaller than responses along other margins (Slemrod 1994) and are often heterogeneously distributed across different types of individuals and workers. ${ }^{1}$ While there are several reasons why this is the case, this paper explores one possible explanation: access to tax evasion opportunities. It is well known that access to evasion opportunities varies across workers thus making it easier for some workers to hide income relative to other workers. For example, whereas many wage earners are subject to third party reporting rendering tax evasion almost impossible, workers in industries that rely on cash payments and the self employed have considerable access to evasion. The objective of the present paper is to test whether these differences in evasion opportunities affect the responsiveness of labor supply to changes in tax rates.

Based on the theoretical framework by Pencavel (1979), we describe the channels through which evasion is likely to affect labor supply elasticities. We conclude that the responsiveness of labor supply varies with the opportunity to evade because workers with evasion opportunities are able to exploit two inter-related margins to adjust their taxable income in response to taxes (labor supply and/or evasion). However, opposing income and substitution effects prevent us from obtaining any clear predictions about the relative magnitude of the effect of access to evasion on the labor supply response. In other words, individuals with an evasion opportunity may have either more or less elastic labor supply responses to tax rate changes, relative to individuals without an opportunity to evade.

We use an empirical approach to answer the research question because of the ambiguous theoretical effect. This is achieved by combining well-established laboratory experimental designs from the evasion and labor literatures. Subjects first complete a real-effort labor task, as in Gill and Prowse (2012), and then make a tax payment. ${ }^{2}$ Subjects are randomly assigned to treatment and control groups that are identical in every respect except for access to evasion; while subjects in the treatment group are able to evade taxes by underreporting their earned income, subjects in the control group cannot. As is common in the experimental tax evasion literature, subjects in the treatment group face an exogenous audit probability and

\footnotetext{
${ }^{1}$ For example, there is evidence that labor supply elasticities vary by gender, with relatively larger estimates for females (Keane 2011), tend to decrease in income (Roed and Strom 2002; Aaberge and Colombino 2006) and vary by marital status (Bargain et al. 2012).

${ }^{2}$ Modeling labor effort instead of labor supply is common in the laboratory experimental literature on labor supply and is usually done because of the difficulty in modeling labor supply as measured by hours of work; e.g., see Dickinson (1999), Falk and Fehr (2003) and Charness and Kuhn (2011) for references and discussion. This issue is discussed further in sections 2.3 and 5.4.
} 
penalty if they are detected (Fortin et al. 2007; Alm et al. 2009). The experiment is set-up such that tax rates vary across rounds, but not between groups. This experimental design allows us to determine if the responsiveness of effort supply with respect to tax rates vary between the two groups. Since access to evasion is the only difference between the two groups, any differences in the observed elasticities can be attributed to the difference in evasion opportunity.

Reliance on experimental methods to answer our research question is motivated by the near impossibility of answering this question with observational data. Tax evasion opportunities are hardly observable ${ }^{3}$ and the standard labor supply elasticities are usually difficult to estimate. Additionally, even if we had good information on evasion opportunities and labor supply responses, clean identification would require us to solve i) reverse causality between tax rates and labor supply and ii) self-selection into jobs with greater access to evasion. The advantage of using an experimental approach is that we are able to randomly assign subjects to treatment states and control the variables of interest, which allows us to cleanly identify the effect of evasion opportunities on labor responses to taxation. Using economic laboratory experimental techniques to analyze supply of effort and tax evasion is not new; see Charness and Kuhn (2011) for a comprehensive survey of the labor effort literature and Graetz et al. (1986), Alm et al. (1992), Fortin et al. (2007), and Alm et al. (2009) for tax evasion examples. ${ }^{4}$

Our experimental results confirm the theoretical prediction that labor responses to tax rates vary with evasion opportunities. In particular, we find evidence that the treatment group is more responsive to tax rate changes than the control group; the effort elasticity with respect to the net-of-tax rate is more negative for participants with the opportunity to evade taxes.

We are among the first to empirically examine the labor supply implications of the observed evidence that tax evasion opportunities are heterogeneously distributed across workers. Whereas studies based on the seminal theory in Allingham and Sandmo (1972) assume that all taxpayers operate in an environment where underreporting is available, more recent studies contradict this view. For example, Slemrod (2007) and Kleven et al. (2011) find evidence of almost no evasion

\footnotetext{
${ }^{3}$ Slemrod and Weber (2012) survey the empirical tax evasion literature and conclude that credible causal evidence is usually not obtained in observational studies. Experiments are one possibility to approach tax evasion issues in a causal manner.

${ }^{4}$ However, in contrast to our work, most experimental contributions in this field look at the amount of evasion as the outcome of interest. Andreoni et al. (1998) and Torgler (2002) provide surveys on tax compliance in experiments. Additionally, our work is different from studies that look at the effect of changes in gross wages, net wages and tax rates; see section 5.3 for a more detailed discussion.
} 
among individuals subject to third-party reporting but substantial evasion among the self-employed. ${ }^{5}$

Additionally, we add to the elasticity of taxable income (ETI) literature and its role in the welfare analysis of tax reforms (Feldstein 1995; Saez et al. 2012) in that we show an additional margin along which ETI varies. In particular, we show that the estimated ETI is 0.96 percentage points higher in the treatment group, which supports the view that tax reforms have heterogeneous effects on individuals and has implications for the structure of optimal tax rates. We interpret this differential effect as evidence that the responsiveness of the tax base is a function of the tax administration environment and recommend that policy makers take steps to minimize evasion opportunities and other avoidance loopholes. This policy is advantageous in that it reduces the responsiveness of the tax base and thus reduces the efficiency cost of tax reforms.

Our paper is related to the literature at the intersection of labor supply and tax evasion. As opposed to theoretical (Sandmo 1981; Cowell 1985) and empirical (Lemieux et al. 1994; Frederiksen et al. 2005) contributions which compare formal and informal labor markets, we compare formal labor markets that have two distinct levels of access to evasion. In this respect, our paper is more in line with the theoretical contributions of Pencavel (1979) and Slemrod (2001) who extend the standard labor supply model with taxes to account for tax evasion and avoidance, respectively. Both papers provide theoretical evidence that the ability to reduce one's tax liability through legal or illegal means affects labor supply decisions.

However, the paper most closely related to ours is Collins et al. (1992) who use a laboratory experimental approach to measure the effect of access to evasion opportunities on the change in labor effort when individuals move from a system with no tax to a system with either a proportional, "mildly progressive", or "steeply progressive" tax system. In other words, their experiment focuses on the progressivity of the tax structure. Their results indicate that the opportunity to evade has a positive effect on labor effort when taxes are proportional or steeply progressive and a negative effect when taxes are mildly progressive. However, it is difficult to tell what the subjects are responding to when the tax regimes in Collins et al. (1992) are implemented; are they responding to the fact that they must now pay taxes, the progressivity of the schedule, the multiple brackets and rates, or the top rate? As a result, the differential effect in effort observed across compliance groups cannot be

\footnotetext{
${ }^{5}$ Other studies show that bunching around kinks in the tax schedule is mostly prevalent among the self-employed, allowing the interpretation that other types of workers simply do not have an opportunity to adjust their taxable income in order to bunch due to lack of evasion opportunities (Saez 2010; Bastani and Selin 2011; Chetty et al. 2012).
} 
interpreted as the causal effect of a change in tax rates. Unlike Collins et al. (1992), we use a flat tax rate that varies across rounds in all sessions. We are therefore the first to directly and cleanly measure the effect of a change in the tax rate on labor effort and to identify how this change varies with access to evasion.

The remainder of the paper is as follows. Section 2 describes the experimental design and set-up. We discuss theoretical predictions in section 3, and present the empirical strategy and results in section 4 . We discuss the empirical findings, ETI implications and issues of external validity in section 5 and conclude the paper in section 6 .

\section{Experimental Design}

We design an experiment where subjects earn income by completing a labor task and then pay taxes on their income. In order to test our hypothesis, one group of subjects is given the opportunity to underreport their income while the other is not. We refer to the group that is given the opportunity to evade as the treatment group, the group that has no evasion opportunity is called the control group. A detailed description of the experimental design is provided below.

\section{$2.1 \quad$ Organization}

The experiment was conducted in the Cologne Laboratory for Economic Research (CLER), University of Cologne, Germany. All subjects in the laboratory's huge subject pool of approximately 4000 persons were invited via email - using the recruitment software ORSEE (Greiner 2004) - to participate in the experiment. Potential participants could sign up on a first-come-first-serve basis. A total of 90 subjects, mostly undergraduate students from the University of Cologne, participated in our experiment. Neither the content of the experiment nor the expected payoff were stated in the invitation email. The computerized experiment was programmed utilizing $z$-tree software (Fischbacher 2007).

We conducted six sessions - three treatment and three control-over three regular school days in June 2012. ${ }^{6}$ The sessions were conducted at 11:00 AM and 3:00 PM each day using the following rotation: Day 1: control then treatment; Day 2: treatment then control; Day 3: control then treatment. Each session included one practice round, 10 paying rounds, 15 subjects, and lasted approximately 70 minutes

\footnotetext{
${ }^{6}$ There are two regular semesters at the tertiary level in Germany; winter semester lasting from October to March and Summer Semester between April and July. Therefore, the experiment was implemented during lecture season and more than 4 weeks before the final exam period.
} 
on average (including review of instructions and payment of participants). Random assignment to computer boothes was implemented by asking each subject to draw an ID number out of a box upon entering the lab. The decisions and payments of the subjects were linked to their ID and the experimenter had no way of matching this information to their names. Subjects also received a hard copy of the instructions when they entered the lab (See appendix D) and were allowed as much time as they needed to familiarize themselves with the procedure of the experiment. They were then given the opportunity to ask any clarifying questions.

\subsection{Overview of a single Round}

At the beginning of each round, participants in both the treatment and the control group were told the tax rate for that round. The tax rate was the same in both groups for a given round. In other words, the treatment status varied between subjects, whereas the tax rate varied within subjects. The tax rate was set at $15 \%$ in the practice round as well as in the first three paying rounds, 35\% in rounds 4 to $6,50 \%$ in rounds 7 to 9 , and $15 \%$ in the last round. In the instructions, participants were told that the "tax rate may, but does not have to, vary from round to round". Therefore, they did not know the tax rate for a given round until the beginning of that round. This option was chosen because we did not want subjects' labor effort decision in round $t$ to be influenced by the tax rate in round $t+1$.

In the treatment group, each round had two stages; a labor task and a reporting decision. In the labor task stage, subjects undertook a real-effort task and earned money depending on their performance on the task. Their gross-income in each round consisted of their labor income plus a fixed amount of non-labor income. In the reporting decision stage, subjects in the treatment group had to report an income amount between zero and their true earned gross income; the reported amount was taxed at the tax rate for that round. These individuals faced an exogenous audit probability of ten percent and paid a fine, which is equal to twice evaded taxes if audited. The audit probability and fine rate were fixed across rounds and participants were given this information at the beginning of the experiment.

Participants in the control group undertook the same labor task as the treatment group, but were not given a reporting decision. That is, they first performed the labor task and earned money based on their performance. Their gross income, earned money from the labor task plus the fixed amount of non-labor income, was then automatically taxed at the tax rate for that round. The tax payment was withdrawn and subjects were informed of their net income for the round. The two stages are explained in more detail in the following two sections. 


\subsection{The Labor Task Stage}

The labor task, which was completed by both groups in the first stage of each round, was designed by Gill and Prowse (2012) and involves moving a set of sliders across a computer screen (see figure 2 in the appendix for a screenshot of the task). ${ }^{7}$ The sliders were initially positioned at zero and could be repositioned to any integer between 0 and 100, inclusive. Subjects received feedback on the current position of the slider only, which was indicated at the rightmost end of each slider. The arrow keys on the key board were disabled to ensure the subjects only used the left mouse key to complete the task; use of the arrow keys makes the task trivial. For each round, subjects were given 2 minutes to align 48 sliders at position 50. As in Gill and Prowse (2012), "the 48 sliders are arranged on the screen so that no two sliders are aligned exactly one under the other." This prevented subjects from positioning one slider at 50 and then visually matching the other sliders at this position. The number of correctly aligned sliders was taken as a measure of labor effort.

The slider task has a number of advantages which are described in Gill and Prowse (2012). It is easy to explain and implement, does not require prior knowledge, does not allow guessing, and is identical across rounds, treatments, and subjects. Most importantly, the slider task generates a lot of variation and it is virtually impossible to move all sliders correctly within the time frame of two minutes. As a result, performance on the task can be interpreted as labor effort. It is important to note that we do not measure hours worked nor do we give subjects the opportunity to substitute "off-the-job" leisure (e.g., taking a day off to go the beach) for effort. This is similar to labor markets in the "real world" that require individuals to work a fixed number of hours each day. Individuals working under these types of contracts often respond to market incentives by changing jobs or by changing their effort on the job. For example, Dickinson (1999) notes that workers can substitute effort for on-the-job leisure such as relaxing in their chair without working. Therefore, our experiment provides participants the opportunity to enjoy on-the-job leisure. We acknowledge that our measure of labor effort cannot be generalized to more traditional measures of labor supply such as hours of work without caution. However, the choices between labor effort and hours of work share many characteristics and are isomorphic in many ways so that our measure of labor effort can serve as a good proxy for labor supply (Charness and Kuhn 2011).

\footnotetext{
${ }^{7}$ Gill and Prowse (2011) provide details and show how to implement the slider task. It has been used widely since its introduction: Gill and Prowse (2010), Riener and Wiederhold (2011), Cettolin and Riedl (2011), Gill and Prowse (2012), Gill et al. (2012), and Hammermann et al. (2012). Djawadi and Fahr (2012) also use the slider task in the context of tax compliance, but examine a different research question than we do and employ compliance as the dependent variable.
} 


\subsection{The Reporting Decision Stage}

Subjects in the treatment group were informed of their gross income, and were asked to make an income reporting decision for tax purposes in the second stage of the experiment. The language used in the instructions and on the computer screen explicitly stated that reported income will be taxed and the instructions also disclosed that all tax revenues will be donated to the German Red Cross. Donating tax revenues to the Red Cross may be viewed as public good, which has been shown to have a positive effect on willingness to pay taxes. ${ }^{8}$

Reported income could be any amount between 0 and true gross income. After the reporting decision was complete, student helpers walked up to each computer booth with a 10 sided die, which each subject threw. The student helper then entered the number thrown on the die in the computer, which then determined the audit status and calculated the subject's tax liability, penalty, if any, and net income. Subjects who underreported income and threw a one were audited and had to pay a fine equal to twice their evaded taxes (i.e., underreported amount multiplied by twice the tax rate). This implies an audit probability of 10 percent, which, together with the fine rate, is a commonly used penalty structure in the tax evasion literature; e.g., see Alm et al. (2009). All other subjects who either reported honestly or underreported but threw a die number between two and ten received a net income equal to true gross income less the tax rate multiplied by the reported gross income. Of course, the student helper could not see if a subject underreported income because the student helper stepped away before the screen summarizing the round's payment appeared. ${ }^{9}$

Unlike the treatment group, subjects in the control group did not have the opportunity to underreport their income and thus could not evade taxes. In other words, their tax liability was "withheld at source". A corollary in the "real" world would be individuals whose only source of income is labor earnings that are subject to third party reporting and withholding and who receive pre-populated tax forms. For example, taxpayers in Germany must enter a tax identification number into their tax forms when filing taxes at the end of the tax year. The tax form is then populated with income information that have been subjected to third party withholding, such as labor income. Therefore, there is no opportunity to underreport income if the

\footnotetext{
${ }^{8}$ See footnote 20 and our conclusion for a discussion and references. We donated 237.91 EURO to the German Red Cross after all six sessions were completed.

${ }^{9}$ The procedure was as follows: The student helper entered the number showing on the face of the die; the subject confirmed this number by hitting "ENTER", which results in a pop-up screen with one of the following sentences: You have been audited or You have not been audited. Afterwards the subject had to press "ENTER" again to see the screen summarizing the round's payment. By this time the student helper would have moved on to the next subject.
} 
only source of income is labor income subject to third party reporting. ${ }^{10}$

Since we are only interested in the extent to which the responsiveness of labor effort varies with evasion status, both groups faced an identical proportional tax rate that varied by round. Subjects were informed of the parameters of the tax system at the beginning of each round. Again, the only difference between treatment and control group was the ability to evade and the only difference between rounds was the tax rate. The empirical analysis in section 4 exploits this between subject variation in treatment.

\subsection{Payment}

Subjects in both groups earned experimental currency units (ECU) throughout the experiment. Their gross income in each round had two parts; earned labor income and non-labor income. The non-labor income was set at five ECU per round and remained constant across subjects and sessions. The labor income was based on performance on the slider task and subjects were paid six ECU for every correctly aligned slider. The net income in each round was a function of gross income, the tax rate, and, in the treatment group, the reporting decision and audit outcome.

After all rounds of a session were completed, each subject threw a 10 sided die to determine which of the 10 rounds she would receive payment for. Paying subjects their net income for a single randomly chosen round instead of the sum of net incomes across all rounds is advantageous because it allows us to avoid wealth effects, satiation, and irrational decisions that generally occur once a certain expected payoff is achieved (see e.g. Blumkin et al. 2012 for a recent example which handles payment in a similar manner). Additionally, this payment method, along with the fact that subjects were not informed about the prevailing tax rate until the start of a round, avoids adding an intertemporal component to our experiment. Therefore, the experiment matches our static theoretical framework and the elasticities we derive ought to be interpreted as static Marshallian ones, as opposed to intertemporal labor substitution elasticities. The total ECU for the selected round was converted

\footnotetext{
${ }^{10}$ We acknowledge that taxpayers in Germany and most other countries who do file still have the opportunity to evade taxes by overstating their deductions. However, this is not an option in our experiment. Even if taxpayers have the opportunity to enter their income on the tax form as is customary in the United States, it would make little sense to underreport income that has been subject to third party reporting since the tax authority has independent information on the correct labor earnings. In other words, the probability of detection is 100 percent for these individuals, which means that underreporting income for tax purposes will lead to lower net income than if gross income were reported accurately. Workers facing these conditions almost always report their true gross income. For example, Slemrod (2007) shows that income subject to third party reporting in the United States has a compliance rate of over 90 percent. We chose to design the experiment similar to the institutional setting of Germany since this is where the experiment was implemented.
} 
to EUROs using an exchange rate of 1 ECU to 0.1 EURO. A show-up fee of 2.5 EURO was added to the subject's net income to determine the final payment. Final payment ranged from 2.50 EURO to 25.2 EURO with an average of 10.66 EURO in the control group and 12.80 EURO in the treatment group. Subjects' final payment was prepared by one of the experimenters who was locked in a private room for the duration of the experiment and who had no contact with the subjects. Payment was enclosed in an envelope with each subjects' ID written on the outside.

\section{Theoretical Framework}

This section of the paper sets up a theoretical framework used to discuss the main channels through which access to evasion affects the responsiveness of labor supply. The model is informed by Pencavel (1979) who merges the standard neo-classical labor supply model with the Allingham and Sandmo (1972) model of tax evasion. We also make reference to results from the standard labor supply model with taxation but no evasion.

\subsection{Model}

Individuals make a labor supply decision $L$, which yields labor income $w L$ and nonlabor income $M ; w$ is the wage rate. They then report $R \leq(w L+M)$ to the tax authority to determine their tax liability. Reported income $R$ is audited with probability $p$ and, because we assume all audits lead to the full discovery of true income, a fine equal to twice the evaded taxes must be paid if audited. Assuming individuals consume all of their income implies:

$$
\text { Consumption }=\left\{\begin{aligned}
C_{a} & =(w L+M)-\tau R-2 \tau(w L+M-R) \\
& =(w L+M)(1-2 \tau)+\tau R \text { with probability p } \\
C_{n} & =w L+M-\tau R \text { with probability }(1-\mathrm{p})
\end{aligned}\right.
$$

where subscripts $a$ and $n$ indicate audited and not audited, respectively, and $\tau$ is the proportional tax rate.

As in Pencavel (1979), we assume individuals choose $L$ and $R$ to maximize an expected utility function that satisfies the standard assumptions of the neo-classical labor supply model; continuous, twice differentiable, and concave. We also assume the utility function is strongly separable in consumption and labor (Pencavel 1979). With these assumptions in mind, the individual maximization problem is specified 
as follows

$$
\begin{aligned}
\max E U=p U\left(C_{a}, L\right)+(1-p) U\left(C_{n}, L\right) & \\
\text { st. } & \\
C_{a} & =(w L+M)(1-2 \tau)+\tau R \\
C_{n} & =w L+M-\tau R,
\end{aligned}
$$

This model reduces to the standard labor supply model with taxation if there is no opportunity to evade. Differentiating equation (2) with respect to $R$ and $L$, respectively, yields first order conditions, which can be used to determine the effect of evasion on the responsiveness of labor supply. Since the derivations are similar to those presented in Pencavel (1979), we discuss the implications here and leave a formal derivation of the main results for appendix $\mathrm{C}$.

\subsection{Prediction}

The derivations presented in appendix $\mathrm{C}$ yields the following result. An increase in the tax rate reduces the return on effort, which reduces effort via an income effect and increases effort via a substitution effect. Because these effects work in opposite directions, their net effect on the responsiveness of effort supply is ambiguous. These standard income and substitution effects are similar to those derived in the standard labor supply model and they apply to both types of workers.

While the discussion above represents the total effect on workers who do not have tax evasion opportunities, there is an additional effect on workers who are able to hide income from the tax authorities. For this group of workers, higher taxes are likely to lead to higher evasion (Alm 2012), which implies a higher net wage. This evasion-induced effect on net wages has income and substitution effects on the responsiveness of labor effort. Increased evasion implies higher net wage and thus higher income, which implies lower work effort via the income effect if leisure is a normal good. At the same time, the higher net wage implies that leisure is more costly thus leading to a substitution towards greater effort. The sign of these evasion-induced income and substitution effects are not only opposite each other, but also opposite the sign of the standard income and substitution effects. Assuming leisure is a normal good, the evasion-induced income effect reinforces the standard substitution effect while the evasion-induced substitution effect reinforces the standard income effect. Therefore, the net effect on evaders depends on the size of the evasion-induced effects relative to the standard effects.

Because the effect of taxes on both groups is ambiguous, it is not clear whether 
workers with evasion opportunities are more or less responsive than workers without such opportunities. This ambiguity makes sense since workers with evasion opportunities have two interrelated means of changing their taxable income in response to a change in the tax rate; work less and/or report less income. We are therefore forced to rely on an empirical analysis to answer our research question.

\section{Empirical Strategy and Results}

In this section, we empirically test whether labor supply responses indeed depend on access to evasion opportunities. We are particularly interested in identifying the effect of tax rates on participants with an evading opportunity relative to those without access to evasion.

Participants in our experiment are randomly assigned to either the treatment or control group and since the treatment status of a given participant is always the same we employ a between-subjects design to identify our coefficient of interest. Furthermore, because we are only interested in the labor effort changes with respect to varying tax rates, we average (collapse) the decisions of each individual by tax rate. ${ }^{11}$ Therefore, our data set has four observations per person; average behavior over rounds $1,2,3$; over rounds $4,5,6$; over rounds $7,8,9$; and finally behavior in round 10. It follows that we compare average behavior across changes in the tax rate as is usually done in the ETI literature (Saez et al. 2012). Analyzing the data in this way also allows us to abstract from learning effects occurring within rounds for which there are no tax changes. It is further consistent with the notion that people adjust to the prevailing tax rate across periods (i.e., years) without tax changes, whereas policymakers are mostly interested in the effects of an actual change in the tax rate.

\subsection{Summary Statistics and Comparisons of Means}

Before estimating regression models, we present summary statistics and compare differences in relevant variables across the two groups. In experiments with random assignment to treatments, a statistically significant difference in the means of the variables of interest across the treatments is usually a valid indicator for the presence of (causal) treatment effects.

Table 1 presents summary statistics of demographic and attitudinal variables separately for both groups. After the experiment, we surveyed tax morale using

\footnotetext{
${ }^{11}$ Recall that the tax rate is 15 percent in rounds 1 to 3,35 percent in rounds 4 to 6,50 percent in rounds 7 to 9 , and 15 percent in round 10 .
} 
a question very similar to the one in the World Values Survey (Minkov 2012). ${ }^{12}$ We also derived a measure of risk aversion by asking subjects to choose between a certain pay-off of $\$ 50$ and a gamble that pays $\$ 100$ with probability of 0.5 and $\$ 0$ with probability of 0.5. Casual observation of the data shows that randomization into the treatment states worked well. This is confirmed by Wilcoxon rank-sum tests for differences in distributions between groups (Wilcoxon 1945; Mann and Whitney 1947) $;^{13}$ we do not observe any statistically significant differences in demographic characteristics (gender, age, share of participants whose native language is German) and attitudinal variables (tax morale, risk aversion) across the two groups. Among all participants, approximately $40 \%$ were male , $74 \%$ indicated German to be their native language, and the average age was 24.1 years. The standard deviation of age is quite high in the self-reporting treatment due to the fact that four persons in this treatment were older than 30 , with one participant being 65 ; only one person in the control group was older than 30 (33 years old). As a robustness check, we exclude all participants older than 30 from our analysis and find that this has no effect on our findings. The average tax morale is 6.94 on a scale of one to ten with ten being the highest level of morale.

Table 1: Summary Statistics

\begin{tabular}{l|cc|cc|c|c}
\hline \hline \multirow{2}{*}{ Variable } & \multicolumn{2}{|c|}{ Control } & \multicolumn{2}{c|}{ Treatment } & & \\
\hline Male & Mean & Std. Dev. & Mean & Std. Dev. & $p>|z|$ & $\mathrm{N}$ \\
Age & 0.36 & 0.48 & 0.44 & 0.50 & 0.392 & 90 \\
German native & 23.33 & 2.98 & 24.78 & 7.43 & 0.783 & 90 \\
Tax Morale & 0.76 & 0.44 & 0.73 & 0.45 & 0.810 & 90 \\
Risk Aversion & 1.36 & 2.72 & 6.93 & 2.48 & 0.797 & 90 \\
\hline \hline
\end{tabular}

Means and Standard Deviations of demographic and attitudinal variables by Treatment Status. Male and German native are dummy variables. $p>|z|$ reports the p-value of a (non-parametric) Wilcoxon rank-sum test for differences in distributions (H0: no differences) between the two treatment groups (Wilcoxon 1945; Mann and Whitney 1947). $N$ indicates the number of observations in both treatments $(N / 2$ per treatment).

In Table 2, we present summary statistics for two of the choice variables in our

12 "Please tell me for the following statement whether you think it can always be justified, never be justified, or something in between: "Cheating on taxes if you have the chance'." This is the most frequently used question to measure tax morale in observational studies (e.g. Doerrenberg and Peichl 2011).

${ }^{13} \mathrm{~A}$ difference in distributions usually implies a difference in means. The Wilcoxon rank-sum test is basically the non-parametric equivalent to a t-test for differences in means. It is the most common test in experimental economics to test for differences between treatment states. 
experiment: labor effort and evasion decision. Panel A shows that participants in the treatment group failed to report roughly $70 \%$ of their gross income on average. Regarding labor effort, summarized in Panel B of Table 2, we see that participants in both groups correctly adjusted 19.2 sliders during the two minutes in each round. We do not find any differences in the level of effort across the two groups: although the means slightly differ in levels, 19.49 among the treated and 19 within the control group, they are not significantly different from each other in a statistical sense (pvalue Wilcoxon rank-sum test: 0.614). Looking at the effort decisions for each round separately, the pattern is similar: the number of correctly positioned sliders does not statistically differ across the two groups.

Table 2: Effort and Evasion

\begin{tabular}{|c|c|c|c|c|c|c|c|}
\hline \multirow[b]{2}{*}{ Variable } & \multirow[b]{2}{*}{$P$} & \multicolumn{2}{|c|}{ Control } & \multicolumn{2}{|c|}{ Treatment } & \multirow[b]{2}{*}{$p>|z|$} & \multirow[b]{2}{*}{$\mathrm{N}$} \\
\hline & & Mean & Std. Dev. & Mean & Std. Dev. & & \\
\hline \multicolumn{8}{|c|}{ Panel A: Evasion } \\
\hline Evasion & all & / & / & 0.71 & 0.34 & 1 & 45 \\
\hline Evasion & 1 & 1 & 1 & 0.60 & 0.39 & 1 & 45 \\
\hline Evasion & 2 & / & / & 0.74 & 0.35 & / & 45 \\
\hline Evasion & 3 & / & / & 0.76 & 0.36 & / & 45 \\
\hline Evasion & 4 & / & / & 0.72 & 0.38 & / & 45 \\
\hline \multicolumn{8}{|c|}{ Panel B: Effort } \\
\hline Effort & all & 19.0 & 4.39 & 19.49 & 4.94 & 0.614 & 90 \\
\hline Effort & 1 & 17.06 & 4.10 & 17.73 & 4.64 & 0.526 & 90 \\
\hline Effort & 2 & 18.62 & 4.45 & 19.59 & 5.08 & 0.283 & 90 \\
\hline Effort & 3 & 19.50 & 5.05 & 20.48 & 5.49 & 0.467 & 90 \\
\hline Effort & 4 & 20.82 & 5.22 & 20.18 & 5.47 & 0.656 & 90 \\
\hline
\end{tabular}

Means and Standard Deviations by Treatment Status and Periods P. Effort is the number of correctly positioned sliders. Evasion is the share of gross income not reported. $p>|z|$ reports the p-value of a (non-parametric) Wilcoxon ranksum test for differences in distributions (H0: no differences) between the two treatment groups (Wilcoxon 1945; Mann and Whitney 1947). In Panel A, $N$ indicates the number of observations in the treatment group. In Panel $B, N$ is the number of observations in both treatment groups, i.e., $N / 2$ per treatment.

Figure 1 presents the trend in effort over the four periods for each of the treatment states. It can be seen that there is an upward trend suggesting a learning effect (as also found in Gill and Prowse 2012). However, it also shows that the adjustment to changing tax rates might be different across the treatment states as indicated by the different slopes of the two graphs between each period.

As our research question is ultimately about different adjustments of labor 


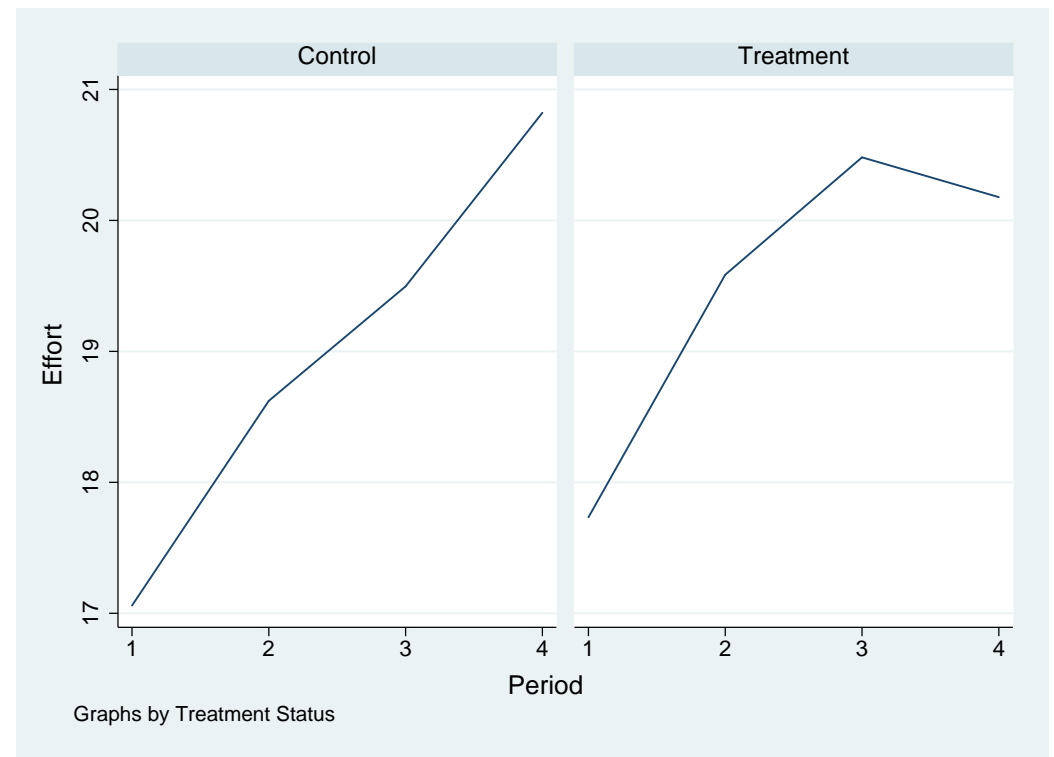

Figure 1: Effort by period and treatment status

effort in response to tax rates, we generate a variable for each person that measures the difference in labor effort between periods $t$ and $t-1$. Table 3 first shows averages in means for the two groups over all rounds: in the control group, participants have a higher average effort adjustment (1.25) than in the treatment group (0.81). This difference is statistically significant at the $5 \%$ level with a p-value of 0.033 for the Wilcoxon rank-sum test and is supported by a simple random effects regression of effort adjustment on the treatment dummy using all panel observations (results available upon request). These results represent our first piece of empirical evidence that labor effort responses are indeed different across the two groups.

Next, we do period-by-period comparison of labor adjustments between the groups. The results, also presented in Table 3, suggest that the above presented differences seem to be mostly driven by the drop in the tax rate between the third and fourth period. Although the means of the variables are different across the treatment groups in levels in each round, they are only significantly different from each other in the last period (p-value Wilcoxon rank-sum test: 0.013). That is, the effort adjustments with response to the tax rate differ the most between the treatment states when the tax rate drops from $50 \%$ to $15 \%$ after the third period. 
Table 3: Effort Adjustments

\begin{tabular}{l|c|cc|cc|c|c}
\hline \hline \multirow{2}{*}{ Variable } & \multirow{2}{*}{} & \multicolumn{2}{|c|}{ Control } & \multicolumn{2}{c|}{ Treatment } & & \\
\hline Effort change & all & 1.25 & 1.07 & 0.81 & 0.97 & 0.033 & 90 \\
\hline Effort change & 1 & $/$ & $/$ & $/$ & $/$ & $/$ & $/$ \\
Effort change & 2 & 1.56 & 2.61 & 1.85 & 2.37 & 0.651 & 90 \\
Effort change & 3 & 0.87 & 2.12 & 0.90 & 2.12 & 0.958 & 90 \\
Effort change & 4 & 1.33 & 3.00 & -0.30 & 2.42 & 0.013 & 90 \\
\hline \hline
\end{tabular}

Means and Standard Deviations by Treatment Status and Periods P. Effort change is the difference in correctly positioned sliders between period $P$ and the previous period, $P-1 . p>|z|$ reports the p-value of a (non-parametric) Wilcoxon rank-sum test for differences in distributions (H0: no differences) between the two treatment groups (Wilcoxon 1945; Mann and Whitney 1947). N indicates the number of observations in both treatments $(N / 2$ per treatment).

\subsection{Regression Analyses}

\subsubsection{Empirical Model}

In a further effort to analyze our research question, we use regression analyses to relate labor effort decisions to changes in the net-of-tax rate (NTR), which is defined as (1 - tax rate). ${ }^{14}$ We test for differences in the labor effort responses to NTRs across the treatment groups by estimating the following model:

$$
L_{i, r, s}=\beta_{0}+\beta_{1}\left(1-\tau_{r}\right)+\beta_{2} T_{s}+\delta\left(1-\tau_{r}\right) T_{s}+\epsilon_{i, r, s},
$$

where $L_{i, r, s}$ indicates labor effort of individual $i$ (with $i=1, \ldots, 90$ ) in treatment state $s$ (with $s=0,1$ ) and round (period) $r$ (with $r=1,2,3,4) .\left(1-\tau_{r}\right.$ ) stands for the net-of-tax rate NTR, and $T_{s}$ is a dummy for the treatment state: either control (dummy is zero) or treatment (dummy is one) group. $\epsilon_{i, r, s}$ is a standard error term. Our coefficient of interest is $\delta$ which represents the difference in the effect of taxes on supply of effort across the two groups. More precisely, $\delta$ indicates the effect of the NTR in the treatment group compared to the control group. Due to random assignment of participants to the two groups, our experimental set-up allows us to causally identify parameter $\delta$. Besides looking at the variables in levels, we also run models in which we use the logged levels of labor effort $L_{i, r, s}$ and $\left(1-\tau_{r}\right)$. That is, we additionally identify the differences in labor effort elasticities with respect to the tax rate across the two treatment states.

\footnotetext{
${ }^{14}$ Estimating the effect of NTR rather than the tax rate is standard in both the labor supply literature (Keane 2011) and the public finance literature (Saez et al. 2012).
} 
As a result of randomization, equation 3 identifies the causal impact of interest without any need for further adjustments. However, identifying the effect of interest, $\delta$, using equation 3 implies that participants in the two treatment states make the same progress in learning how to play the effort task. In order to ensure that different learning abilities across the two groups do not confound our results, we further run models of the form:

$$
L_{i, r, s}=\beta_{0}+\beta_{1}\left(1-\tau_{r}\right)+\beta_{2} T_{s}+\delta\left(1-\tau_{r}\right) T_{s}+\eta P_{r}+\epsilon_{i, r, s}
$$

where the notation is the same as in equation 3 and $P_{r}$ is a linear learning trend which takes the values 1, 2, 3 or 4 for each period. We also run specifications including the logged value of $P_{r}\left(\log \left(P_{r}\right)\right)$ to account for potentially diminishing learning trend. As will be discussed further below, our results do not change when we control for learning trends, indicating that randomization into treatments indeed worked. We did not include period fixed effects because the NTR does not vary within a given period.

In the appendix, we also present results where we include control variables to verify that our results are not driven by other confounding variables across the treatment states. These include age, gender, a dummy for German being the native language, risk aversion, tax morale, and a dummy for the time of the day a participant's session was run (morning or afternoon). The fact that the results of interest are not altered by controlling for these variables provides further evidence that randomization worked well. Moreover, Table 9 in the appendix displays estimates from regressions in which we estimate the above models separately for both groups.

We set-up our data as a panel with 90 individuals and four observations per individual. We run random effects (GLS) regressions with standard errors clustered on individuals. ${ }^{15}$ Random effects regressions yield unbiased results because random selection into treatments and exogenous tax rates cause the error term to be uncorrelated with our explanatory variable of interest in each time period (Wooldridge 2010). ${ }^{16}$ Obviously, because the treatment status of a single individual never changes, it is not possible to estimate the treatment effect in the presence of individual fixed effects.

\footnotetext{
${ }^{15}$ Because our sample is relatively small, we also estimated robustness checks where we use block bootstrapped standard errors (blocked by the individual, 500 drawing repetitions) (Efron and Tibshirani 1994; Bertrand et al. 2004). This did not affect the precision of the standard errors.

${ }^{16}$ Note that the labor decision is not censored from above, making the use of estimators that allow for censoring, such as Tobit models, unnecessary. Table 2 depicts that the average number of correctly adjusted sliders was 19.2 (out of 48). The maximum number of correct positions was 32.42 suggesting that it was impossible to reach the upper bound of 48 .
} 


\subsubsection{Regression Results}

Levels Table 4 depicts the results of our main regressions. The results obtained by regressing effort on the independent variables show a positive significant treatment effect; the statistically significant interaction term effect $\delta$ suggests that participants in the treatment group are more responsive to changes in the NTR. The coefficient of -3.056 in column $I$ implies that a rise in the net-of-tax rate by one percentage point decreases the supply of labor effort in the treatment group by 3.056 correctly positioned sliders more than in the control group. This effect is entirely robust to the inclusion of a linear time trend (column $I I$ ) or logged time trend (column $I I I$ ). Table 6 in the appendix shows that the results are also robust to the inclusion of a set of additional control variables. Given the robustness of our results with respect to both the time trend and additional control variables, we are confident that our estimates of the differential effect $\delta$ are not driven by confounding variables.

Table 4: Regression of Effort on Taxes

\begin{tabular}{lccc}
\hline \hline & $\mathrm{I}$ & $\mathrm{II}$ & $\mathrm{III}$ \\
\hline NTR $\times$ Treat & $-3.056^{* *}$ & $-3.056^{* *}$ & $-3.056^{* *}$ \\
& $(1.398)$ & $(1.400)$ & $(1.400)$ \\
NTR & -1.130 & -0.273 & 1.078 \\
& $(1.082)$ & $(1.092)$ & $(1.119)$ \\
Treated & $2.672^{*}$ & $2.672^{*}$ & $2.672^{*}$ \\
& $(1.535)$ & $(1.537)$ & $(1.537)$ \\
Trend (linear) & & $0.993^{* * *}$ & \\
& & $(0.107)$ & \\
Trend (log) & & & $2.226^{* * *}$ \\
& & & $(0.237)$ \\
Constant & $19.805^{* * *}$ & $16.713^{* * *}$ & $16.464^{* * *}$ \\
& $(1.093)$ & $(1.103)$ & $(1.107)$ \\
\hline Panel Obs & 360 & 360 & 360 \\
Indiv. Obs & 90 & 90 & 90 \\
Periods & 4 & 4 & 4 \\
R2 & 0.01 & 0.06 & 0.06 \\
\hline \hline
\end{tabular}

Random Effects Regressions. Dependent Variable is Effort. Standard Errors in parentheses are clustered by Individual. Treated is a dummy variable taking "1" if a participant is in the group with evasion opportunity (treated) and " 0 " if not. NTR (net-of-tax rate) is defined as (1 - Tax Rate). Significance levels: $*<0.10, * *<0.05, * * *<0.01$ 
Table 9 in the appendix reports results for the same regression specifications, but separately for both treatments. The results depict a non-significant effect for the control group and a negative and statistically significant effect for the treatment group. However, the estimated elasticities cannot be interpreted as causal effects because the confounding time trend is either omitted or (possibly) not correctly specified. Nonetheless, the results provide further evidence that responses to taxation are different between the two groups.

Elasticities Next, we reestimate the models in logs in order to obtain an elasticity interpretation. The results reported in Table 7 in the appendix again confirm that access to evasion increases the responsiveness of effort supply to NTRs. A $1 \%$ increase in the NTR decreases labor effort in the treatment group by 0.123 percentage points relative to the control group. These results remain stable when we add control variables to the regressions (see table 8 in the appendix).

\section{Discussion of Results}

Our findings show that access to evasion opportunities is an important determinant of how individuals' labor efforts respond to changes in tax rates. This section first provides an economic intuition of our main results (5.1) and then proceeds to discuss implications of our findings for the elasticity of taxable income (ETI), the optimal tax rate, as well as tax revenue (5.2). Afterwards, we also discuss how our experimental design differs from studies that focus on the effect of wages and taxes (5.3) as well as the external validity of our findings (5.4).

\subsection{Labor Supply Responses}

We find workers without evasion opportunities to have lower labor effort responses to tax rates than workers with evasion opportunities. ${ }^{17}$ This finding is not surprising in light of empirical evidence in the labor supply literature (Duncan and Sabirianova Peter 2010; Keane 2011; Bargain et al. 2012) and suggests that small labor supply elasticities observed over all workers might be driven by workers without evasion opportunities who usually represent the largest share of workers. What is rather revealing though, is the fact that individuals with evasion opportunities are relatively more (less) responsive to taxes. While interesting, this result makes

\footnotetext{
${ }^{17}$ Results from regressions in which the elasticities are estimated separately for the two groups (Table 9) reveal zero elasticities in the control group, which is somewhat in accordance with the literature that finds very small responses. However, we cannot entirely rule out that these coefficients are confounded by an either omitted or falsely specified time trend.
} 
sense when one considers the fact that individuals with evasion opportunities have two interrelated margins along which to adjust their income; labor effort and reported income. One possible explanation for our result is that an increase in the tax rate increases labor effort via an income effect and reduces labor effort via a substitution effect. However, just as in the control group, these standard income and substitution effects are likely to cancel out. At the same time, the higher tax rate induces an increase in evasion, which leads to higher net-wages, all else equal. The higher net-wage, in turn, leads to additional income and substitution effects which are induced by the evasion response. While this income effect reduces labor effort, the substitution effect increases effort. Our results suggest that this latter substitution effect outweighs all other effects.

\subsection{Implications}

The result described above has implications for the elasticity of taxable income (ETI), optimal tax rates and the tax revenue. First, results presented in specifications $I, I I$ and $I I I$ of Table 5 show that access to evasion is an important determinant of the ETI. We find that the ETI is 0.964 percentage points higher in the treatment group relative to the control group. ${ }^{18}$ In this sense, our findings are consistent with the observation that bunching around kink points in the tax schedule is more prevalent among the self-employed who have greater access to evasion (Saez 2010; Bastani and Selin 2011; Chetty et al. 2012). Finding that the ETI is relatively higher in the treatment group is also consistent with recent work by Burns and Ziliak (2012) who find that the ETI increases with education and is greater than one for individuals with a graduate degree as well as Heim (2009, 2010) who shows that the ETI is increasing in income and larger for the self-employed. We argue that our findings represent one possible explanation for these results since well-educated individuals with higher incomes and a higher propensity to be self-employed are more likely to have better evasion opportunities.

Second, the results also suggest that optimal tax policy must consider the behavioral implications of evasion. For example, access to evasion increases the responsiveness of the tax base thus forcing policy makers to adopt discriminatory tax rates; higher rates on non-evaders. However, similar to Slemrod and Kopczuk (2002) and Kopczuk (2005) we argue that policy makers should direct resources towards minimizing evasion opportunities and other avoidance loopholes. Doing

\footnotetext{
${ }^{18}$ Finding that the coefficients do not depend on the inclusion of a time trend, we provide more evidence that our results are not confounded by differences in learning effects between the two groups.
} 
so reduces the responsiveness of the tax base and allows policy makers to adopt relatively uniform tax rates. Finally, specifications $I V, V$ and $V I$ in Table 5 show that the effect of tax rates on tax revenue differs across the two groups as expected; the effect of the net-of-tax rate is less negative in the control group. Descriptive statistics (not reported) reveal that the average tax payment per person is more than twice as high in the control than in the treatment group. This suggests that the responsiveness of individuals, especially those in the treatment group, is inelastic, which is consistent with estimates that rely on "real" observational data (Saez et al. 2012).

An obvious caveat to our experimental findings is the fact that our experimental set-up mirrors a world where only two channels are available to adjust taxable income. It is not immediately clear what the implications are for a model with more than two response margins. We leave such considerations for future research.

Table 5: Effect of Taxes on Taxable Income and Revenue

\begin{tabular}{|c|c|c|c|c|c|c|}
\hline & I & II & III & IV & V & VI \\
\hline Dep. Var: & \multicolumn{3}{|c|}{ Taxable Inc (log) } & \multicolumn{3}{|c|}{ Tax revenue $(\log )$} \\
\hline NTR $(\log ) \times$ Treat & $\begin{array}{l}0.964^{* * *} \\
(0.369)\end{array}$ & $\begin{array}{l}0.964^{* * *} \\
(0.370)\end{array}$ & $\begin{array}{l}0.964^{* * *} \\
(0.370)\end{array}$ & $\begin{array}{l}1.808^{* * *} \\
(0.387)\end{array}$ & $\begin{array}{l}1.808^{* * *} \\
(0.387)\end{array}$ & $\begin{array}{l}1.808^{* * *} \\
(0.387)\end{array}$ \\
\hline NTR (log) & $\begin{array}{c}-0.044 \\
(0.041)\end{array}$ & $\begin{array}{c}-0.056 \\
(0.047)\end{array}$ & $\begin{array}{c}-0.078 \\
(0.067)\end{array}$ & $\begin{array}{c}-2.312^{* * *} \\
(0.040)\end{array}$ & $\begin{array}{c}-2.301^{* * *} \\
(0.045)\end{array}$ & $\begin{array}{c}-2.281^{* * *} \\
(0.061)\end{array}$ \\
\hline Treated & $\begin{array}{c}-2.364^{* * *} \\
(0.297)\end{array}$ & $\begin{array}{c}-2.364^{* * *} \\
(0.297)\end{array}$ & $\begin{array}{c}-2.364^{* * *} \\
(0.297)\end{array}$ & $\begin{array}{c}-1.131^{* * *} \\
(0.193)\end{array}$ & $\begin{array}{c}-1.131^{* * *} \\
(0.193)\end{array}$ & $\begin{array}{c}-1.131^{* * *} \\
(0.193)\end{array}$ \\
\hline Trend (linear) & & $\begin{array}{c}-0.017 \\
(0.034)\end{array}$ & & & $\begin{array}{c}0.016 \\
(0.030)\end{array}$ & \\
\hline Trend (log) & & & $\begin{array}{c}-0.048 \\
(0.079)\end{array}$ & & & $\begin{array}{c}0.046 \\
(0.068)\end{array}$ \\
\hline Constant & $\begin{array}{l}4.731^{* * *} \\
(0.037)\end{array}$ & $\begin{array}{l}4.770^{* * *} \\
(0.086)\end{array}$ & $\begin{array}{l}4.758^{* * *} \\
(0.057)\end{array}$ & $\begin{array}{l}2.558^{* * *} \\
(0.033)\end{array}$ & $\begin{array}{l}2.521^{* * *} \\
(0.077)\end{array}$ & $\begin{array}{l}2.533^{* * *} \\
(0.050)\end{array}$ \\
\hline Panel Obs & 360 & 360 & 360 & 360 & 360 & 360 \\
\hline Indiv. Obs & 90 & 90 & 90 & 90 & 90 & 90 \\
\hline Periods & 4 & 4 & 4 & 4 & 4 & 4 \\
\hline $\mathrm{R} 2$ & 0.49 & 0.49 & 0.49 & 0.48 & 0.48 & 0.48 \\
\hline
\end{tabular}

Random Effects Regressions by Treatment Status. Dependent Variable is Logged Taxable Income in I, II III and Logged Tax Revenue in $I V, V$ and VI. NTR (net-of-tax rate) is defined as (1 - Tax Rate). Standard Errors in parentheses are clustered by Individual. Significance levels: $*<0.10, * *<0.05, * * *<0.01$

\subsection{Evasion vs. Net Wage and Effective Tax Rate}

We acknowledge that providing one group of workers the opportunity to hide taxable income might be viewed as equivalent to a reduction in the effective tax rate of this 
group and therefore an increase in the net wage rate (Rosen 1976a, 1976b). This argument suggests that our experiment is eventually similar to other experimental studies examining the effect of wage rates or tax rates on supply of effort in standard real-effort tasks. However, several theoretical and empirical studies show that people respond differently to taxes than they do to wages (Koenig et al. 1995; Slemrod 2001; Fochman and Weimann 2011; Fochman et al. 2012), which suggests that the impact of evasion opportunities on effort supply in our experiment is not equivalent to the effect of the net wage rate.

We further argue that our experiment differs from experimental set-ups which examine the effect of varying effective tax rates on real-effort because the implicit reduction in effective tax rates due to evasion opportunities is not salient to our participants. This view is supported by recent empirical evidence gathered via field and lab experiments which finds that taxes are perceived only imperfectly and that "salience" as well as context are important determinants of individuals" responses to tax changes (Sausgruber and Tyran 2005; Finkelstein 2009; Chetty et al. 2009; Blumkin et al. 2012). Additionally, our subjects have to take an explicit action, underreporting, in order to benefit from a lower tax burden. Because this action is costly due to risk and loss aversion or subjective moral costs of evading (Doerrenberg et al. 2012), it is likely to illicit different behavioral responses than an explicit exogenous change in effective tax rates that would not be associated with any costs. The observation that people substantially overestimate risks (Tversky and Kahneman 1974) further supports our argument that (risky) evasion opportunities are not equivalent to reductions in effective tax rates or net wages.

\subsection{External Validity}

As with all economics laboratory experiments, there remains doubt about the external validity of our results. ${ }^{19}$ One major concern is that the setting in the lab is abstract and artificial. In our experiment, however, we rely on a "real-effort" experiment in which subjects have to work on an actual task and earn money dependent on their performance. While not perfectly equivalent to a naturally occurring environment, the effort task represents real economic choices and is similar to many "real world" labor tasks in the sense that it is annoying and somewhat "painful". Again, we acknowledge the need to exercise caution when generalizing labor effort decisions to more traditional labor supply decisions such as hours worked. However, since the choices between effort and hours worked are isomorphic in many ways

\footnotetext{
${ }^{19}$ See Levitt and List (2007) for a critical discussion of the generalizability of lab experiments. Falk and Heckman (2009) offer a defense of most concerns, some of which are also discussed here.
} 
(Charness and Kuhn 2011) and share many characteristics, we argue that choices in the real-effort experiment can serve as a good proxy for actual labor supply. In order to make the tax evasion decision as realistic as possible we used actual tax terminology and announced to the participants that all tax revenue will be donated to the German Red Cross, a non-ideological charity organization that is usually perceived as reliable and transparent. ${ }^{20}$

It is also often argued that the stakes in lab experiments are too small to interpret the outcomes as realistic. This is unlikely to be true in our case because our average pay-off of EUR 11.73 corresponds to more than five full lunch meals in the student cafeteria at Cologne University. ${ }^{21}$ Furthermore, many experiments conducted in locations where the stakes were equivalent to more than a month's earnings find very similar results to conventional "small-stake" experiments (Slonim and Roth 1998). Additionally, it is questionable if high stakes render a more realistic setting since most "real-life" decisions do not involve massive amounts of money (Falk and Heckman 2009). Another concern is the reliance on university students as participants. Many experiments with non-student populations find results comparable to experiments with students (Charness and Kuhn 2011; Falk et al. 2012). Furthermore, Alm et al. (2011) compare students to non-students in tax compliance experiments and find that reporting responses of students to policy innovations are largely the same as non-students in identical experiments and "real" people in non-experiment environments.

\section{Conclusion}

Motivated by the observation that some types of workers have the opportunity to hide their income while others do not have such opportunities, this paper is the first to cleanly identify the differential effect of access to evasion opportunities on labor supply elasticities with respect to tax rates. We first use a theoretical framework to describe the channels through which evasion is likely to affect labor supply elasticities. A lab experiment is then utilized to test the theoretical prediction that access to evasion influences the responsiveness of labor supply to tax rates. In the experiment, all subjects first undertake a simple labor effort task and then have to pay taxes on the income they earn from the labor task. The tax rate varies across

\footnotetext{
${ }^{20}$ Tax morale research (Torgler 2007) finds that taxpayers are more likely to comply with the tax laws if they believe that the tax revenue is spent transparently. Eckel and Grossman (1996) show that dictators share more in dictator games if the recipient is the American Red Cross. Overall, we donated EUR 237,91 to the Red Cross.

${ }^{21}$ The show-up fee is equivalent to one meal. The cafeteria at University of Cologne is the most popular spot for students to buy their daily lunch.
} 
the rounds and is announced before each new round. A treatment group is given the opportunity to report their income either correctly or falsely, while the control group does not have the opportunity to evade and their tax liability is simply withdrawn. We find evidence that access to evasion increases the responsiveness of labor effort supply.

Our results provide one possible explanation for why observed labor supply elasticities might be different across different types of workers. Workers with a reporting decision, i.e., the opportunity to evade taxes, have two channels to adjust their taxable income, labor supply and evading, whereas workers who are subject to third-party reporting are only able to resort to labor adjustments. The present paper is the first to empirically show that heterogeneous access to evasion opportunities, as found in recent empirical studies (Kleven et al. 2011; Chetty et al. 2012), have an impact on economic decisions such as labor supply. We also find that the ETI is relatively larger among individuals with access to evasion. The combination of positive labor effort elasticity and positive ETI implies that the reporting response is greater than the real (labor effort) response for individuals in the treatment group, which is consistent with the hierarchical structure of behavioral responses described by Slemrod (1992). Together, these results imply that tax reform evaluations ought to consider how behavioral responses to tax policy varies across individuals.

Our results suggest that policy makers ought to adopt discriminatory tax rates; higher rates on non-evaders. Otherwise, workers with access to evasion are likely to adjust their taxable income considerably in response to tax changes, which yields excessive distortions and welfare losses. However, we argue that policy makers should strive to minimize evasion/avoidance loopholes instead of adopting discriminatory tax rates. Minimizing evasion and avoidance opportunities would reduce the responsiveness of the tax base and allow for more uniform tax rates, which may be higher or lower. A similar argument is made by Piketty et al. (2011) who argue that avoidance responses to higher tax rates restrict the scope to increase top tax rates. Closing loopholes would also lead to equity gains by ensuring that the effective tax rate is equal across all types of workers all else equal (Alm and Finlay 2012).

We acknowledge that external validity has to be considered when extrapolating the results to the "real" world. However, just as with field-experiments and quasi-experimental observational studies, we argue that our results should be interpreted as Local Average Treatment Effects (LATE) that provide causal evidence on a particular sub-population. 


\section{A The Slider Task}

Figure 2: Screen showing the slider task

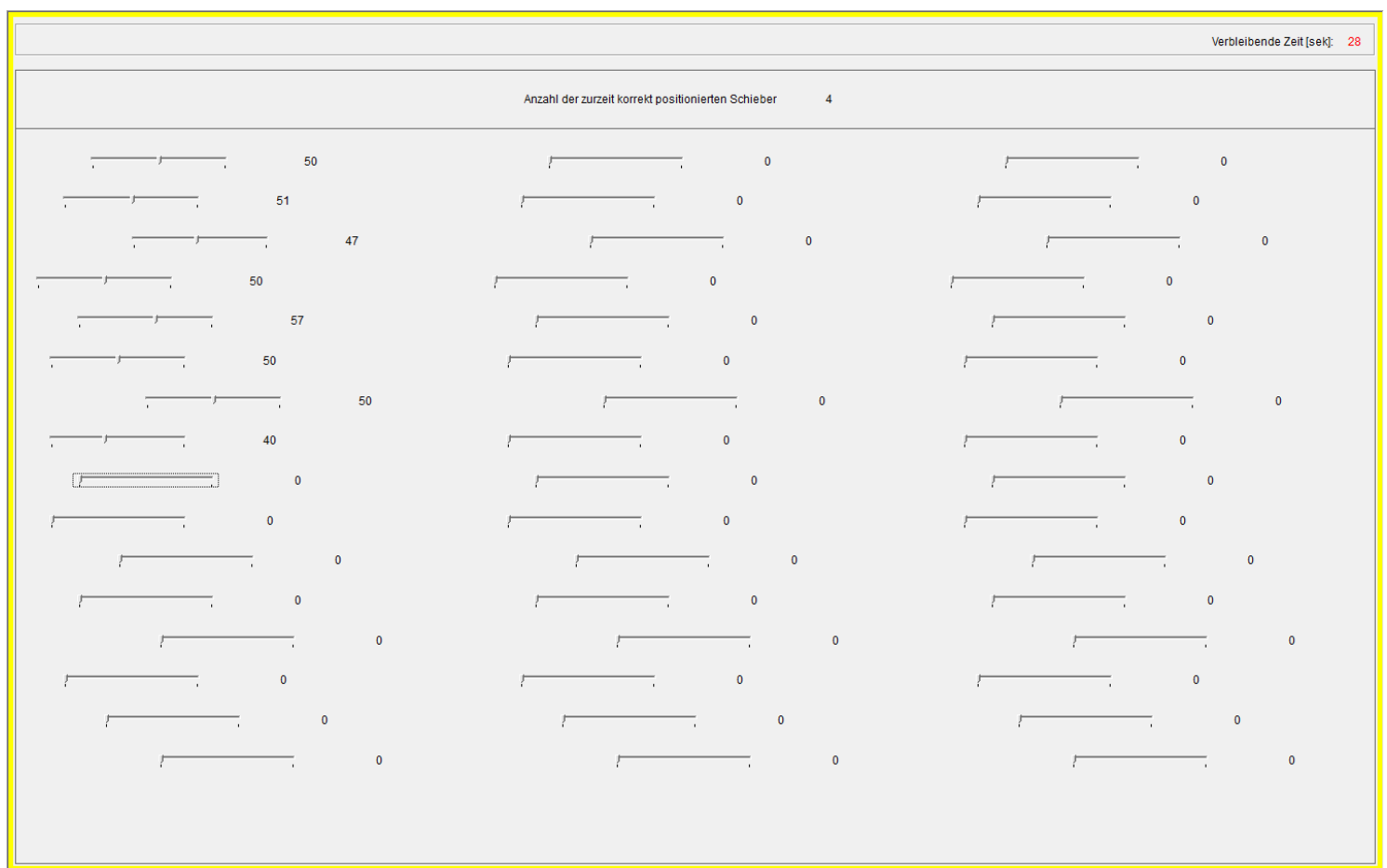

Note: The slider task was designed by Gill and Prowse (2012). In the displayed screen, the subject positioned four sliders correctly and four falsely. She currently works on positioning the ninth slider. 28 seconds are left in this round.

\section{B Regression Tables}


Table 6: Regression of Effort on NTR with controls

\begin{tabular}{|c|c|c|c|}
\hline & $\mathrm{I}$ & II & III \\
\hline NTR $\times$ Treat & $\begin{array}{c}-3.056^{* *} \\
(1.410)\end{array}$ & $\begin{array}{c}-3.056^{* *} \\
(1.412)\end{array}$ & $\begin{array}{c}-3.056^{* *} \\
(1.412)\end{array}$ \\
\hline NTR & $\begin{array}{r}-1.130 \\
(1.091)\end{array}$ & $\begin{array}{r}-0.273 \\
(1.101)\end{array}$ & $\begin{array}{c}1.078 \\
(1.128)\end{array}$ \\
\hline Treated & $\begin{array}{c}2.209 \\
(1.404)\end{array}$ & $\begin{array}{c}2.209 \\
(1.406)\end{array}$ & $\begin{array}{c}2.209 \\
(1.406)\end{array}$ \\
\hline Male & $\begin{array}{l}3.247^{* * *} \\
(0.847)\end{array}$ & $\begin{array}{l}3.247^{* * *} \\
(0.848)\end{array}$ & $\begin{array}{l}3.247^{* * *} \\
(0.848)\end{array}$ \\
\hline Age & $\begin{array}{c}-0.145^{* *} \\
(0.062)\end{array}$ & $\begin{array}{c}-0.145^{* *} \\
(0.062)\end{array}$ & $\begin{array}{c}-0.145^{* *} \\
(0.062)\end{array}$ \\
\hline Time of day & $\begin{array}{c}1.631^{*} \\
(0.849)\end{array}$ & $\begin{array}{c}1.631^{*} \\
(0.850)\end{array}$ & $\begin{array}{c}1.631^{*} \\
(0.850)\end{array}$ \\
\hline German Native & $\begin{array}{l}2.829 * * \\
(1.199)\end{array}$ & $\begin{array}{l}2.829 * * \\
(1.200)\end{array}$ & $\begin{array}{l}2.829^{* *} \\
(1.200)\end{array}$ \\
\hline Risk Aversion & $\begin{array}{c}0.753 \\
(0.728)\end{array}$ & $\begin{array}{c}0.753 \\
(0.729)\end{array}$ & $\begin{array}{c}0.753 \\
(0.729)\end{array}$ \\
\hline Tax Morale & $\begin{array}{r}-0.269 \\
(0.186)\end{array}$ & $\begin{array}{r}-0.269 \\
(0.186)\end{array}$ & $\begin{array}{r}-0.269 \\
(0.186)\end{array}$ \\
\hline Trend (linear) & & $\begin{array}{l}0.993^{* * *} \\
(0.108)\end{array}$ & \\
\hline Trend (log) & & & $\begin{array}{c}2.226^{* * *} \\
(0.239)\end{array}$ \\
\hline Constant & $\begin{array}{l}18.541^{* * *} \\
(2.811)\end{array}$ & $\begin{array}{l}15.449^{* * *} \\
(2.860)\end{array}$ & $\begin{array}{l}15.200^{* * *} \\
(2.863)\end{array}$ \\
\hline Panel Obs & 360 & 360 & 360 \\
\hline Indiv. Obs & 90 & 90 & 90 \\
\hline Periods & 4 & 4 & 4 \\
\hline $\mathrm{R} 2$ & 0.30 & 0.35 & 0.35 \\
\hline
\end{tabular}

Random Effects Regressions. Dependent Variable is Effort. Standard Errors in parentheses are clustered by Individual. Treated is a dummy variable taking " 1 " if a participant is in the group with evasion opportunity (treated) and " 0 " if not. NTR (net-of-tax rate) is defined as (1 - Tax Rate). Significance levels: $*<0.10, * *<0.05, * * *<0.01$ 
Table 7: Regressions of Logged Effort on Logged NTR

\begin{tabular}{lccc}
\hline \hline & I & II & III \\
\hline NTR $(\log ) \times$ Treat & $-0.123^{* *}$ & $-0.123^{* *}$ & $-0.123^{* *}$ \\
& $(0.056)$ & $(0.056)$ & $(0.056)$ \\
NTR $(\log )$ & -0.025 & 0.011 & 0.058 \\
& $(0.045)$ & $(0.045)$ & $(0.046)$ \\
Treated & -0.021 & -0.021 & -0.021 \\
& $(0.054)$ & $(0.054)$ & $(0.054)$ \\
Trend (linear) & & $0.053^{* * *}$ & \\
& & $(0.006)$ & \\
Trend (log) & & & $0.120^{* * *}$ \\
& & & $(0.013)$ \\
Constant & $2.895^{* * *}$ & $2.775^{* * *}$ & $2.830^{* * *}$ \\
& $(0.035)$ & $(0.036)$ & $(0.035)$ \\
\hline Panel Obs & 360 & 360 & 360 \\
Indiv. Obs & 90 & 90 & 90 \\
Periods & 4 & 4 & 4 \\
R2 & 0.01 & 0.05 & 0.05 \\
\hline \hline
\end{tabular}

Random Effects Regressions. Dependent Variable is logged Effort. Standard Errors in parentheses are clustered by Individual. Treated is a dummy variable taking " 1 " if a participant is in the group with evasion opportunity (treated) and "0" if not. NTR (net-of-tax rate) is defined as (1 Tax Rate). Significance levels: $*<0.10, * *<0.05, * * *$ $<0.01$ 
Table 8: Regressions of Logged Effort on Logged NTR with controls

\begin{tabular}{|c|c|c|c|}
\hline & $\mathrm{I}$ & II & III \\
\hline NTR $(\log ) \times$ Treat & $\begin{array}{c}-0.123^{* *} \\
(0.057)\end{array}$ & $\begin{array}{c}-0.123^{* *} \\
(0.057)\end{array}$ & $\begin{array}{c}-0.123^{* *} \\
(0.057)\end{array}$ \\
\hline NTR (log) & $\begin{array}{r}-0.025 \\
(0.046)\end{array}$ & $\begin{array}{c}0.011 \\
(0.046)\end{array}$ & $\begin{array}{c}0.058 \\
(0.046)\end{array}$ \\
\hline Treated & $\begin{array}{r}-0.045 \\
(0.048)\end{array}$ & $\begin{array}{r}-0.045 \\
(0.048)\end{array}$ & $\begin{array}{r}-0.045 \\
(0.048)\end{array}$ \\
\hline Male & $\begin{array}{l}0.180^{* * *} \\
(0.043)\end{array}$ & $\begin{array}{l}0.180 * * * \\
(0.043)\end{array}$ & $\begin{array}{l}0.180 * * * \\
(0.043)\end{array}$ \\
\hline Age & $\begin{array}{c}-0.009^{* *} \\
(0.003)\end{array}$ & $\begin{array}{c}-0.009^{* *} \\
(0.003)\end{array}$ & $\begin{array}{c}-0.009^{* *} \\
(0.003)\end{array}$ \\
\hline Time of day & $\begin{array}{c}0.086^{*} \\
(0.047)\end{array}$ & $\begin{array}{c}0.086^{*} \\
(0.047)\end{array}$ & $\begin{array}{c}0.086^{*} \\
(0.047)\end{array}$ \\
\hline German Native & $\begin{array}{l}0.173^{* *} \\
(0.071)\end{array}$ & $\begin{array}{l}0.173^{* *} \\
(0.071)\end{array}$ & $\begin{array}{l}0.173^{* *} \\
(0.071)\end{array}$ \\
\hline Risk Aversion & $\begin{array}{c}0.029 \\
(0.038)\end{array}$ & $\begin{array}{c}0.029 \\
(0.038)\end{array}$ & $\begin{array}{c}0.029 \\
(0.038)\end{array}$ \\
\hline Tax Morale & $\begin{array}{r}-0.014 \\
(0.009)\end{array}$ & $\begin{array}{r}-0.014 \\
(0.009)\end{array}$ & $\begin{array}{r}-0.014 \\
(0.009)\end{array}$ \\
\hline Trend (linear) & & $\begin{array}{l}0.053^{* * *} \\
(0.006)\end{array}$ & \\
\hline Trend (log) & & & $\begin{array}{l}0.120^{* * *} \\
(0.013)\end{array}$ \\
\hline Constant & $\begin{array}{l}2.842^{* * *} \\
(0.155)\end{array}$ & $\begin{array}{l}2.722^{* * *} \\
(0.157)\end{array}$ & $\begin{array}{l}2.777^{* * *} \\
(0.156) \\
\end{array}$ \\
\hline Panel Obs & 360 & 360 & 360 \\
\hline Indiv. Obs & 90 & 90 & 90 \\
\hline Periods & 4 & 4 & 4 \\
\hline $\mathrm{R} 2$ & 0.31 & 0.36 & 0.36 \\
\hline
\end{tabular}

Random Effects Regressions. Dependent Variable is logged Effort. Standard Errors in parentheses are clustered by Individual. Treated is a dummy variable taking " 1 " if a participant is in the group with evasion opportunity (treated) and "0" if not. NTR (net-of-tax rate) is defined as (1 Tax Rate). Significance levels: $*<0.10, * *<0.05, * * *$ $<0.01$ 
Table 9: Regression of Effort on NTR by Treatment Status

\begin{tabular}{lcccccc}
\hline \hline & I & II & III & IV & V & VI \\
\hline Group: & Control & Treated & Control & Treated & Control & Treated \\
\hline NTR & -1.130 & $-4.185^{* * * *}$ & -0.081 & $-3.521^{* * *}$ & 1.563 & $-2.464^{* * *}$ \\
& $(1.086)$ & $(0.890)$ & $(1.107)$ & $(0.894)$ & $(1.162)$ & $(0.928)$ \\
Trend (linear) & & & $1.215^{* * *}$ & $0.770^{* * *}$ & & \\
& & & $(0.154)$ & $(0.141)$ & & \\
Trend (log) & & & & & $2.716^{* * *}$ & $1.736^{* * *}$ \\
& & & & & $(0.344)$ & $(0.314)$ \\
Constant & $19.805^{* * *}$ & $22.477^{* * *}$ & $16.020^{* * *}$ & $20.077^{* * *}$ & $15.728^{* * *}$ & $19.870^{* * *}$ \\
& $(1.097)$ & $(1.082)$ & $(1.122)$ & $(1.072)$ & $(1.130)$ & $(1.076)$ \\
\hline Panel Obs & 180 & 180 & 180 & 180 & 180 & 180 \\
Indiv. Obs & 45 & 45 & 45 & 45 & 45 & 45 \\
Periods & 4 & 4 & 4 & 4 & 4 & 4 \\
R2 & 0.001 & 0.01 & 0.08 & 0.04 & 0.08 & 0.04 \\
\hline \hline
\end{tabular}

Random Effects Regressions by Treatment Status. Dependent Variable is Effort. Standard Errors in parentheses are clustered by Individual. NTR (net-oftax rate) is defined as ( $1-$ Tax Rate). Significance levels: $*<0.10, * *<0.05$, $* * *<0.01$

\section{Theoretical model}

This section of the appendix outlines a simple theoretical framework that captures the main features of the labor supply and evasion decision that individuals face in the treatment group as defined in section 2. The model merges the standard neoclassical labor supply model with the Allingham and Sandmo (1972) model of tax evasion (Pencavel 1979). We acknowledge that the theoretical framework used here models labor supply as hours of work rather than effort, which is the basis of our experimental design. However, as discussed in section 2.5, the choices between labor effort and hours of work share many characteristics and are isomorphic in many ways so that modeling labor effort in a labor supply framework should nonetheless yield valid hypotheses for our experimental set-up. Modeling labor supply instead of effort also eases the comparison with the standard labor supply model.

Because the model describing the control group is the standard labor supply model, we simply state the results of this model where appropriate without any derivations.

\section{C.1 Model}

Individuals make a labor supply decision $L$, which yields labor income $w L$ and nonlabor income $M ; w$ is the wage rate. They then report $R \leq(w L+M)$ to the 
tax authority to determine their tax liability. Reported income $R$ is audited with probability $p$ and, because we assume all audits lead to the full discovery of true income, a fine equal to twice the evaded taxes must be paid if audited. Assuming individuals consume all of their income implies:

$$
\text { Consumption }=\left\{\begin{aligned}
C_{a} & =(w L+M)-\tau R-2 \tau(w L+M-R) \\
& =(w L+M)(1-2 \tau)+\tau R \text { with probability p } \\
C_{n} & =w L+M-\tau R \text { with probability }(1-\mathrm{p})
\end{aligned}\right.
$$

where subscripts $a$ and $n$ indicate audited and not audited, respectively, and $\tau$ is the proportional tax rate.

As in Pencavel (1979), we assume individuals choose $L$ and $R$ to maximize an expected utility function that satisfies the standard assumptions of the neo-classical labor supply model; continuous, twice differentiable, and concave. We also assume the utility function is strongly separable in consumption and labor (Pencavel 1979). With these assumptions in mind, the individual maximization problem is specified as follows

$$
\begin{aligned}
\max E U=p U\left(C_{a}, L\right)+(1-p) U\left(C_{n}, L\right) & \\
\text { st. } & \\
C_{a} & =(w L+M)(1-2 \tau)+\tau R \\
C_{n} & =w L+M-\tau R,
\end{aligned}
$$

Differentiating equation (6) with respect to $R$ and $L$, respectively, yields the following first order conditions:

$$
\begin{aligned}
p U_{C_{a}}^{\prime} t-(1-p) U_{C_{n}}^{\prime} \tau & =0 \\
p U_{C_{a}}^{\prime} w(1-2 \tau)+p U_{L}^{\prime}+(1-p) U_{C_{n}}^{\prime} w+(1-p) U_{L}^{\prime} & =0,
\end{aligned}
$$

which we rewrite as

$$
\begin{gathered}
p U_{C_{a}}^{\prime}=(1-p) U_{C_{n}}^{\prime} \\
w=-\frac{U_{L}^{\prime}}{p(1-2 \tau) U_{C_{a}}^{\prime}+(1-p) U_{C_{n}}^{\prime}}
\end{gathered}
$$

Assuming interior solutions exist, it can be shown from equation (8) that utility is maximized by the level of reported income that equalizes the weighted marginal utility of consumption in both states of the world. Similarly, equation (9) implies individuals choose the level of labor supply that equalizes the wage rate to the ratio 
of the marginal utility of labor and the expected marginal utility of consumption. This is comparable to the equilibrium condition facing our non-evader treatment in the standard neoclassical labor supply model with taxes and no tax evasion; $w=-\frac{U_{L}^{\prime}}{(1-\tau) U_{C}^{\prime}}$.

\section{C.2 Maximum exists}

This section of the appendix shows that the conditions for a maximum are satisfied. To see this we differentiate the equations in (7) with respect to $L$ and $R$ to get:

$$
V=\left[\begin{array}{ll}
A & B \\
C & D
\end{array}\right]
$$

where $A=\left[p w^{2} \gamma^{2} U_{C_{a}}^{\prime \prime}+q w^{2} U_{C_{n}}^{\prime \prime}+U_{L}^{\prime \prime}\right], B=\left[p w \gamma \tau U_{C_{a}}^{\prime \prime}-q w \tau U_{C_{n}}^{\prime \prime}\right], C=\left[p \gamma w U_{C_{a}}^{\prime \prime}-\right.$ $\left.q w U_{C_{n}}^{\prime \prime}\right]$, and $D=\left[p \tau U_{C_{a}}^{\prime \prime}+q \tau U_{C_{n}}^{\prime \prime}\right]$, and $q=(1-p)$ and $\gamma=(1-2 \tau)$. Maximum requires that $V$ is negative definite; i.e.; $A<0$ and $\Lambda=A * D-B * C>0$. A is less than zero as long as $U_{C_{a}}^{\prime \prime}<0, U_{C_{n}}^{\prime \prime}<0$, and $U_{L}^{\prime \prime}<0$. Therefore, we need to show that $\Lambda=A * D-B * C>0$.

It can be shown that

$$
\begin{aligned}
A * D & =\left(p w \gamma U_{C_{a}}^{\prime \prime}\right)^{2} \tau+p q(w \gamma)^{2} \tau U_{C_{a}}^{\prime \prime} U_{C_{n}}^{\prime \prime}+p q w^{2} \tau U_{C_{a}}^{\prime \prime} U_{C_{n}}^{\prime \prime}+(q w)^{2} \tau\left(U_{C_{n}}^{\prime \prime}\right)^{2}+p \tau U_{C_{a}}^{\prime \prime} U_{L}^{\prime \prime}+q \tau U_{C_{n}}^{\prime \prime} U_{L}^{\prime \prime} \\
& =p^{2} w^{2} \tau U_{C_{n}}^{\prime \prime} U_{C_{a}}^{\prime \prime}\left[\gamma^{2} \frac{U_{C_{a}}^{\prime \prime}}{U_{C_{n}}^{\prime \prime}}+\frac{q}{p} \gamma^{2}+\frac{q}{p}+\frac{q^{2}}{p} \frac{U_{C_{n}}^{\prime \prime}}{U_{C_{a}}^{\prime \prime}}\right]+p \tau U_{L}^{\prime \prime}\left[U_{C_{a}}^{\prime \prime}+\frac{q}{p} U_{C_{n}}^{\prime \prime}\right]
\end{aligned}
$$

and that

$$
\begin{aligned}
B * C & =\left(p w \gamma U_{C_{a}}^{\prime \prime}\right)^{2} \tau-p q \gamma w^{2} \tau U_{C_{a}}^{\prime \prime} U_{C_{n}}^{\prime \prime}-p q w^{2} \gamma \tau U_{C_{a}}^{\prime \prime} U_{C_{n}}^{\prime \prime}+(q w)^{2} \tau\left(U_{C_{n}}^{\prime \prime}\right)^{2} \\
& =p^{2} w^{2} \tau U_{C_{n}}^{\prime \prime} U_{C_{a}}^{\prime \prime}\left[\gamma^{2} \frac{U_{C_{a}}^{\prime \prime}}{U_{C_{n}}^{\prime \prime}}-2 \frac{q}{p} \gamma+\frac{q^{2}}{p} \frac{U_{C_{n}}^{\prime \prime}}{U_{C_{a}}^{\prime \prime}}\right]
\end{aligned}
$$

Therefore,

$$
A * D-B * C=p^{2} w^{2} \tau U_{C_{n}}^{\prime \prime} U_{C_{a}}^{\prime \prime}(1+\gamma)^{2}+p \tau U_{L}^{\prime \prime}\left[U_{C_{a}}^{\prime \prime}+\frac{q}{p} U_{C_{n}}^{\prime \prime}\right]>0 \quad \text { Q.E.D. }
$$

\section{C.3 Comparative Statics}

This section of the appendix derives comparative static results for our theoretical model. We are particularly interested in the effect of non-labor income and the tax rate on labor supply. Start by totally differentiating the equations in (7) under the 
assumption that $d \tau=d w=0, d m \neq 0, d L \neq 0$, and $d R \neq 0$. This yields:

$$
\begin{array}{r}
p w \gamma U_{C_{a}}^{\prime \prime}(\gamma w d L+\gamma d M+\tau d R)+q w U_{C_{n}}^{\prime \prime}(w d L+d M-t d R)+U_{L}^{\prime \prime} d L=0 \\
p U_{C_{a}}^{\prime \prime}(\gamma w d L+\gamma d M+\tau d R)-q U_{C_{n}}^{\prime \prime}(w d L+d M-t d R)=0
\end{array}
$$

where $q=(1-p)$ and $\gamma=(1-2 \tau)$. Rewrite equation (14) $\operatorname{as}^{22}$

$$
\begin{aligned}
& A d L+B d R+G d M=0 \\
& A d L+B d R+H d M=0
\end{aligned}
$$

and solve for the income effect to get:

$$
\frac{d L}{d M}=-\frac{p q w \tau U_{C_{a}}^{\prime \prime} U_{C_{n}}^{\prime \prime}(1+\gamma)^{2}}{\Lambda} \leq 0
$$

This result implies that labor supply is an inferior good; i.e., an increase in non-labor income reduces labor supply. ${ }^{23}$

Similarly, the effect of true income on reported income is:

$$
\begin{aligned}
\frac{d R}{d M} & =\frac{\left(p(1-2 \tau) \frac{U_{C_{a}}^{\prime \prime}}{U_{C_{n}}^{\prime \prime}}-q\right)}{\Lambda} \lessgtr 0 \\
& =\frac{(1-p) U_{C_{a}}^{\prime \prime} U_{L}^{\prime \prime}\left(\frac{R_{c c}^{a}}{R_{c n}^{a}}(1-2 \tau)-1\right)}{\Lambda},
\end{aligned}
$$

where $R_{c i}^{a}$ is the measure of absolute risk aversion in state $i$.

Next we derive the effect of tax rate on labor supply by totally differentiating the equations in (7) under the assumption that $d M=d w=0, d \tau \neq 0, d L \neq 0$, and $d R \neq 0$. This yields:

$$
\begin{aligned}
-2 p w U_{C_{a}}^{\prime} d \tau+p w \gamma U_{C_{a}}^{\prime \prime}[\gamma w d L-2 I d \tau+\tau d R+R d \tau]+q w U_{C_{n}}^{\prime \prime}[w d L-\tau d R-R d \tau]+U_{L}^{\prime \prime} d L & =0 \\
p U_{C_{a}}^{\prime \prime}(\gamma w d L-2 I d \tau+\tau d R+R d \tau)-q U_{C_{n}}^{\prime \prime}(w d L-\tau d R-R d \tau) & =0
\end{aligned}
$$

which we rewrite $\operatorname{as}^{24}$

$$
\begin{aligned}
& A d L+B d R-E d \tau=0 \\
& C d L+D d R-F d \tau=0
\end{aligned}
$$

${ }^{22} \mathrm{~A}, \mathrm{~B}, \mathrm{C}$, and D are as defined earlier while $G=p w \gamma U_{C_{a}}^{\prime \prime}+q w U_{C_{n}}^{\prime \prime}$, and $H=p \gamma U_{C_{a}}^{\prime \prime}-q U_{C_{n}}^{\prime \prime}$.

${ }^{23}$ The effect of non-labor income on labor supply would be ambiguous as in the standard labor supply model had we not imposed the strong separability assumption.

${ }^{24} \mathrm{~A}, \mathrm{~B}, \mathrm{C}$, and D are as defined earlier while $E=\left[2 p w U_{C_{a}}^{\prime}+2 p w I \gamma U_{C_{a}}^{\prime \prime}-p w \gamma R U_{C_{a}}^{\prime \prime}+q w R U_{C_{n}}^{\prime \prime}\right]$ and $F=\left[2 p I U_{C_{a}}^{\prime \prime}-p R U_{C_{a}}^{\prime \prime}-q R U_{C_{n}}^{\prime \prime}\right]$. 
Rewriting equation (14) in matrix form and solving for $\frac{d L}{d t}$ yields:

$$
\frac{d L}{d \tau}=\overbrace{\frac{p^{2} w \tau U_{C_{a}}^{\prime} U_{C_{a}}^{\prime \prime} Z}{\Lambda}}^{1} \overbrace{\frac{p w \tau U_{C_{a}}^{\prime \prime} U_{C_{n}}^{\prime \prime} Q}{\Lambda}}^{2} \overbrace{-\frac{d L}{d M} \frac{(w L+M)}{(1-\tau)}}^{3} \lessgtr 0,
$$

where $^{25}$

$$
\begin{aligned}
& Z=\left[2+2(1-2 \tau)(w L+M-R)+\frac{(1-p)}{p} R \frac{U_{C_{n}}^{\prime \prime}}{U_{C_{a}}^{\prime \prime}}\right] \\
& Q=\left[2(1-2 \tau) \frac{U_{C_{a}}^{\prime \prime}}{U_{C_{n}}^{\prime \prime}}(w L+M)+\left(p(1-2 \tau) \frac{U_{C_{a}}^{\prime \prime}}{U_{C_{n}}^{\prime \prime}}-(1-p)\right) R+2(1-p)\right] \\
& \Lambda=p^{2} w^{2} \tau U_{C_{a}}^{\prime \prime} U_{C_{n}}^{\prime \prime} \frac{(1-p)}{p} 4(1-\tau)^{2}+p \tau U_{L}^{\prime \prime}\left(U_{C_{a}}^{\prime \prime}+\frac{(1-p)}{p} U_{C_{n}}^{\prime \prime}\right)
\end{aligned}
$$

As in the standard model, equation (15) may or may not be negative. The first two terms capture substitution effects and is always negative as long as $\tau<0.5$. In other words, an increase in the tax rate leads to lower labor supply. On the other hand, higher taxes imply lower income, which leads to higher labor supply to compensate for the lost income. This income effect is captured by the third term.

\section{Instructions}

\section{D.1 English translation: Evasion opportunity treatment}

Welcome and thank you for participating in our experiment. From now on until the end of the experiment, please refrain from communicating with other participants. If you do not abide by this rule, we will have to exclude you from the experiment.

We kindly ask you to read the instructions thoroughly. If you have any questions after reading the instructions or during the experiment, please raise your hand and one of the instructors will come to you and answer your question in person. Your payment and your decisions throughout the experiment will be treated confidentially. None of the other participants is informed, neither during nor after the experiment, about your decisions in the experiment or your payment.

You can earn money in this experiment. How much you earn depends on your decisions. During the experiment, your payments will be calculated in a virtual currency: Experimental Currency Units (ETU). 1 ECU corresponds to $\mathbf{0 . 1 0}$

\footnotetext{
${ }^{25}$ Note that $Q>0$ since $2(1-2 \tau) \frac{U_{C_{a}}^{\prime \prime}}{U_{C_{n}}^{\prime \prime}}>\left(p(1-2 \tau) \frac{U_{C_{a}}^{\prime \prime}}{U_{C_{n}}^{\prime \prime}}-(1-p)\right)$, and $w L+M>R$. This
} follows from the fact that $0<p<1$. We also assume $(1-2 \tau)>0$, which requires $\tau<0.5$ as in our experiment. 
Euro. After the experiment, your pay-off will be converted to Euro and given to you in cash. Additionally, you will receive a show-up fee of 2.50 Euro.

\section{The Experiment}

Overview The experiment consists of 11 rounds. In each round, you will first complete a labor task and, depending on your performance, earn money from this labor task. You will have to pay taxes on your earned income. Therefore, after the labor task you will be faced with a tax reporting decision. Both the labor task and the tax return filing are described in more detail further below.

Payment The first of 11 rounds serves as a practice round, in which you cannot earn money. The subsequent 10 rounds are paying rounds. All rounds are independent of each other. What is more, your pay-off does not at all depend on the decisions of other participants. The pay-off, which you will be paid in cash at the end of the experiment, does not consist of the sum of the net incomes from all 10 paying rounds. Instead, after the experiment, one round will be randomly chosen to determine your payment. Practically this means that after all 10 paying rounds have been completed you will throw a 10-sided die. The number shown by the die determines the round for which you will be paid.

Flow of each round You will be told the tax rate for a given round at the beginning of that round. The tax rate may, but does not have to, vary from round to round. In the next step you will complete the labor task on the computer screen. After completion of this labor task, you will be shown your gross income. This is based on your performance during the labor task plus a fixed amount. Details on the labor task are described further below.

After completion of the labor task, you will be faced with a tax reporting decision. You choose an amount, which shall be taxed at the prevailing tax rate. The amount you chose may be as high as your earned gross income or lower. There is a random chance of $10 \%$ that your decision will be checked to see whether you reported your true gross income. If you are not checked, your payment for this round - the net income - will consist of your gross income less the tax payment. If you are checked and you have not fully reported your gross income, you will have to pay a penalty. More details are explained further below. All tax revenues paid by you and all other participants will be donated to the German Red Cross.

In Summary, each of the 11 rounds is timed as follows: 
1. Information on prevailing tax rate

2. Completing the labor task

3. Information on gross income

4. Tax reporting

5. Check whether tax reporting is checked.

6. Calculation of this round's net income

The Labor Task At the beginning of each round you will first be informed about the tax rate in that round. Afterwards, you undertake a labor task on the computer screen using the computer mouse. In each round the task will last 120 seconds. During the task a screen with 48 so-called sliders appears on the screen. Each slider is initially positioned at "0" (Zero) and can be moved by you. You can move the slider to every whole number between " 0 " and "100" by clicking on the slider and moving the computer mouse. The current position of each slider is displayed to the right of this slider. You can readjust the position of each slider as many times as you wish. For each slider that you position exactly at "50" during the 120 seconds, you earn 6 ECU. During the 120 seconds of the labor task, on the upper right of the screen you are shown how many sliders are currently positioned at " 50 ".

The Tax Return In the next step, you are shown on the screen how many ECU you earned in the labor task. Regardless of the ECU you earned based on correctly positioned sliders, you will receive an additional 5 ECU per round. The sum of the income from the labor task and this unconditionally given amount determines your gross income. This is shown on the screen. You are, once more, also shown which tax rate is in force.

You are now asked to report income for tax purposes. You choose an amount which shall be taxed at this round's prevailing tax rate. This chosen amount can be between zero and your gross income.

Calculation of Net Income After the completion of the tax reporting decision, one of the experimental investigators will come up to your booth with a 10-sided die. Please throw this 10-sided die. Based on the result of the die throw, there are two alternative scenarios, of which one is realized.

a) The die shows a number between $\mathbf{2}$ and $\mathbf{1 0}$ (that is, a number out of $2,3, \ldots$, $9,10)$ 
In case the die shows a number between 2 and 10, your reporting decision will not be checked to determine whether you reported your full gross income for tax purposes. Your payment for this round - the net income -, in this case, consists of your gross income (earnings from labor task plus 5 ECU) less the tax payment. Thereby, the tax payment is the reported income multiplied with the prevailing tax rate. Hence:

$\underline{\text { Net income }}=$ gross income $-($ reported amount*tax rate)

b) The die shows the number $\mathbf{1}$ :

In case the die shows the number 1 your reporting decision will be checked to determine whether you reported your full gross income for tax purposes. Depending on your previous decision, there are two different possibilities for your net income:

- If your reported income equals your true gross income, then your net income consists of your gross income less your tax liability. Hence:

$\underline{\text { Net income }}=$ gross income $-\left(\right.$ gross income ${ }^{*}$ tax rate $)$

- If your reported income is lower than your gross income, then you will have to pay the tax liability based on your true gross income and additionally you will have to pay a penalty. This penalty is equal to the difference between your true gross income and your reported income multiplied by the prevailing tax rate. Hence:

$\underline{\text { Net income }}=$ gross income $-($ gross income*tax rate $)-[($ gross income - reported income) $*$ tax rate]

Final Remarks After the completion of all 11 rounds - one practice round plus 10 paying rounds - the experiment is finished. One of the experimental investigators will come up to your booth and, once more, we ask you to throw a 10-sided die. The die throw determines the round (out of the 10 paying rounds) for which you are paid. For example, if the die shows the number "2", then your payment consists of the net income that you earned in the second paying round. In addition, you receive the show-up fee of 2,50 Euro. You will also be asked to complete a short questionnaire at the end of the experiment while we prepare the payments. All 
information collected through this questionnaire, just like all data gathered during the experiment, are anonymous and exclusively used for scientific purposes. After you have completed the questionnaire, please remain seated at your booth until we call you to come up front to pick up your payment.

\section{D.2 English translation: No-Evasion opportunity treatment}

Welcome and thank you for participating in our experiment. From now on until the end of the experiment, please refrain from communicating with other participants. If you do not abide by this rule, we will have to exclude you from the experiment. We kindly ask you to read the instructions thoroughly. If you have any questions after reading the instructions or during the experiment, please raise your hand and one of the instructors will come to you and answer your question in person. Your payment and your decisions throughout the experiment will be treated confidentially. None of the other participants is informed, neither during nor after the experiment, about your decisions in the experiment or your payment. You can earn money in this experiment. How much you earn depends on your decisions. During the experiment, your payments will be calculated in a virtual currency: Experimental Currency Units (ETU). 1 ECU corresponds to 0.10 Euro. After the experiment, your pay-off will be converted to Euro and given to you in cash. Additionally, you will receive a show-up fee of 2.50 Euro.

\section{The Experiment}

Overview The experiment consists of 11 rounds. In each round, you will complete a labor task and, depending on your performance, earn money from this labor task. You will have to pay taxes on your earned income.

Payment The first of 11 rounds serves as a practice round, in which you cannot earn money. The subsequent 10 rounds are paying rounds. All rounds are independent of each other. What is more, your pay-off does not at all depend on the decisions of other participants. The pay-off, which you will be paid in cash at the end of the experiment, does not consist of the sum of the net incomes from all 10 paying rounds. Instead, after the experiment, one round will be randomly chosen to determine your payment. Practically this means that after all 10 paying rounds have been completed you will throw a 10-sided die. The number shown by the die determines the round for which you will be paid. 
Flow of each round You will be told the tax rate for a given round at the beginning of that round. The tax rate may, but does not have to, vary from round to round. In the next step you will complete the labor task on the computer screen. After completion of this labor task, you will be shown your gross income, the prevailing tax rate and your corresponding net income. Your gross income is based on your performance during the labor task plus a fixed amount of 5 ECU. Details on the labor task and calculation of the net income are described further below. All tax revenues paid by you and all other participants will be donated to the German Red Cross.

In Summary, each of the 11 rounds is timed as follows:

a) Information on prevailing tax rate

b) Completing the labor task

c) Information on gross income

d) Calculation of this round's net income

The Labor Task At the beginning of each round you will first be informed about the tax rate in that round. Afterwards, you undertake a labor task on the computer screen using the computer mouse. In each round the task will last 120 seconds. During the task a screen with 48 so-called sliders appears on the screen. Each slider is initially positioned at "0" (Zero) and can be moved by you. You can move the slider to every whole number between " 0 " and "100" by clicking on the slider and moving the computer mouse. The current position of each slider is displayed to the right of this slider. You can readjust the position of each slider as many times as you wish. For each slider that you position exactly at "50" during the 120 seconds, you earn 6 ECU. During the 120 seconds of the labor task, on the upper right of the screen you are shown how many sliders are currently positioned at " 50 ".

Calculation of Net Income After the completion of the tax reporting decision, you will be shown your gross income for this round. The gross income is based on the number of correctly positioned sliders plus a fixed amount of 5 ECU. Your gross income will be taxed at this round's prevailing tax rate. Your payment for this round - the net income -, consists of your gross income less the tax payment. Thereby, the tax payment is the gross income multiplied with the prevailing tax rate. Hence: 
$\underline{\text { Net income }}=$ gross income $-($ gross income*tax rate $)$

Final Remarks After the completion of all 11 rounds - one practice round plus 10 paying rounds - the experiment is finished. One of the experimental investigators will come up to your booth and we ask you to throw a 10-sided die. The die throw determines the round (out of the 10 paying rounds) for which you are paid. For example, if the die shows the number " 2 ", then your payment consists of the net income that you earned in the second paying round. In addition, you receive the show-up fee of 2,50 Euro. You will also be asked to complete a short questionnaire at the end of the experiment while we prepare the payments. All information collected through this questionnaire, just like all data gathered during the experiment, are anonymous and exclusively used for scientific purposes. After you have completed the questionnaire, please remain seated at your booth until we call you to come up front to pick up your payment.

\section{D.3 German original}

The following pages display the original German instructions for both treatment states. $^{26}$

\footnotetext{
${ }^{26}$ In order to indicate to the reader which instructions belong to which treatment status, we put either "Control group" or "Treatment group" in parentheses after the header. Of course, the original version given to the participants did not contain any hint regarding the treatment status.
} 


\section{Instruktionen (Treatment group)}

Herzlich willkommen und vielen Dank für Ihre Teilnahme an unserem Experiment. Bitte kommunizieren Sie ab sofort und bis zum Ende des Experimentes nicht mehr mit anderen Teilnehmern. Sollten Sie sich nicht an diese Regel halten, müssen wir Sie von dem Experiment ausschließen.

Wir bitten Sie, die Instruktionen sehr aufmerksam zu lesen. Wenn Sie nach dem Lesen oder während des Experimentes noch Fragen haben, heben Sie bitte Ihre Hand. Einer der Experimentleiter wird dann zu Ihnen kommen und Ihre Frage persönlich beantworten. Ihre Auszahlung und Ihre Entscheidungen werden vertraulich behandelt. Keiner der anderen Teilnehmer erfährt während oder nach dem Experiment, welche Entscheidungen Sie getroffen haben oder wie hoch Ihre Auszahlung war.

Sie können in diesem Experiment Geld verdienen. Wie viel Sie verdienen, hängt von Ihren Entscheidungen $a b$. Ihre Auszahlungen werden im Laufe des Experimentes in virtuellen Geldeinheiten, den Experimental Currency Units (ECU), gerechnet. 1 ECU entspricht 0,10 Euro. Ihre Auszahlung wird nach dem Ende des Experimentes in Euro umgerechnet und in bar an Sie ausgezahlt. Zusätzlich erhalten Sie für Ihr Erscheinen eine Zahlung in Höhe von 2,50 Euro.

\section{$\underline{\text { Das Experiment }}$}

\section{Übersicht}

Das Experiment besteht aus 11 Runden. In jeder Runde werden Sie zunächst eine Arbeitsaufgabe erledigen und dafür abhängig von Ihrer Leistung Geldeinheiten erhalten. Die von Ihnen verdienten Geldeinheiten aus der Arbeitsaufgabe sind zu versteuern. Daher sind Sie im Anschluss an die Arbeitsaufgabe mit einer Steuererklärung konfrontiert. Sowohl die Arbeitsaufgabe als auch die Steuererklärungsentscheidung werden weiter unten detaillierter erklärt.

\section{Auszahlung}

Die erste der 11 Runden gilt als Übungsrunde, in der Sie kein Geld verdienen können. In den 10 darauffolgenden Auszahlungsrunden können Sie Geld verdienen. Alle Runden sind völlig unabhängig voneinander, außerdem hängt Ihre Auszahlung in keiner Weise von den Entscheidungen oder Leistungen anderer Experimentteilnehmer ab. Die Auszahlung, die am Ende an Sie geleistet wird, besteht nicht aus der Summe Ihrer Nettoeinnahmen aus allen 10 Auszahlungsrunden, sondern es wird im Anschluss an das Experiment zufällig eine Runde ausgewählt, die Ihre Bezahlung bestimmt. Praktisch heißt das, dass Sie nach dem Ende aller Runden einen 10-seitigen Würfel werfen werden. Die Zahl, die der Würfel anzeigt, bestimmt die Runde, auf deren Basis Sie bezahlt werden. 


\section{Ablauf einer Runde}

In jeder Runde wird Ihnen zunächst der in dieser Runde geltende Steuersatz angezeigt. Dieser Steuersatz kann, muss aber nicht, von Runde zu Runde variieren. Im nächsten Schritt absolvieren Sie am Computerbildschirm eine Arbeitsaufgabe. Nach dem Absolvieren dieser Arbeitsaufgabe wird Ihnen Ihr Bruttoeinkommen angezeigt, das auf Ihrer Arbeitsleistung zuzüglich eines fixen Betrags basiert. In jeder Runde gilt für alle Teilnehmer derselbe Steuersatz. Einzelheiten zu der Arbeitsaufgabe sind weiter unten beschreiben.

Nach dem Absolvieren der Arbeitsaufgabe sind Sie mit einer Steuererklärung konfrontiert. Sie benennen einen Betrag zwischen Null und der Höhe Ihres Bruttoeinkommens, der mit dem jeweils geltenden Steuersatz versteuert werden soll. Es besteht eine zufällige Chance von 10\%, dass überprüft wird, ob Sie Ihr Bruttoeinkommen in voller Höhe angeben haben. Werden Sie nicht überprüft, dann besteht Ihre Auszahlung für diese Runde - das Nettoeinkommen - aus Ihrem Bruttoeinkommen abzüglich der Steuerzahlung. Sollten Sie überprüft werden und Sie haben Ihr Bruttoeinkommen nicht in voller Höhe angegeben, dann fällt eine Strafe an. Die Einzelheiten sind weiter unten beschrieben. Alle von Ihnen geleisteten Steuerzahlungen werden an das Deutsche Rote Kreuz gespendet.

$\rightarrow$ Zusammengefasst läuft jede der 11 Runden des Experiments wie folgt ab:

1. Information über geltenden Steuersatz

2. Absolvieren der Arbeitsaufgabe

3. Information über erwirtschaftetes Bruttoeinkommen

4. Steuererklärung

5. Überprüfung, ob die Steuererklärung überprüft wird

6. Berechnung des Nettoeinkommens dieser Runde

\section{Die Arbeitsaufgabe}

Am Anfang einer jeden Runde erfahren Sie zunächst den für diese Runde geltenden Steuersatz. Danach erledigen Sie an dem vor Ihnen stehenden Bildschirm eine Arbeitsaufgabe mit Hilfe der Computermaus. In jeder Runde wird die Arbeitsaufgabe genau 120 Sekunden andauern. Während der Arbeitsaufgabe erscheint ein Bildschirm, auf dem 48 sogenannte Schieber zu sehen sind. Jeder Schieber ist zunächst bei der Position „, 0 “ (Null) positioniert und kann von Ihnen verschoben werden. Sie können den Schieber auf jede ganze Zahl zwischen „0“ und „100“ verschieben, indem Sie den Schieber mit der Maus anklicken und die Maus bewegen. Rechts neben dem Schieber wird die aktuelle Position angezeigt. Sie können jeden Schieber so oft verschieben, wie Sie möchten. Sie erhalten für jeden Schieber, den Sie innerhalb der 120 Sekunden exakt an der Nummer „50“ positionieren 6 ECU. Oben in der Mitte können Sie während der 120 Sekunden immer ablesen, wie viele Schieber Sie aktuell bei „50“ positioniert haben. 


\section{Die Steuererklärung}

Im nächsten Schritt wird Ihnen am Bildschirm angezeigt, wie viel ECU Sie zuvor bei der Arbeitsaufgabe erwirtschaftet haben. Neben den ECU, die Sie auf Basis der erfolgreich auf „50“ positionierten Schieber erreicht haben, erhalten Sie zusätzlich einen Betrag von 5 ECU pro Runde. Die Summe aus den Einnahmen aus der Arbeitsaufgabe und diesem von der Arbeitsaufgabe unabhängig gewährten Betrag ist Ihr Bruttoeinkommen. Dieses wird Ihnen angezeigt. Ebenfalls wird Ihnen auf dem Computerbildschirm auch nochmal angezeigt, welcher Steuersatz in dieser jeweiligen Runde gilt.

Sie sind nun aufgefordert eine Steuererklärungsentscheidung zu treffen. Sie benennen einen Betrag, der mit dem jeweils in dieser Runde geltenden Steuersatz besteuert werden soll. Dieser von Ihnen genannte Betrag kann zwischen Null und der Höhe Ihres zuvor gesamten erreichten Bruttoeinkommens liegen.

\section{Berechnung des Nettoeinkommens}

Nachdem Sie ihre Steuererklärungsentscheidung getroffen haben, warten Sie bitte bis einer der Experimentleiter an Ihren Platz kommt. Der Experimentleiter wird einen 10-seitigen Würfel mitbringen, der wird von Ihnen geworfen wird. Basierend auf dem Ergebnis des Würfelwurfs ergeben sich zwei mögliche Szenarien, von denen sich eins realisiert:

a) Der Würfel zeigt eine Zahl zwischen 2 und 10 (also eine Zahl aus 2,3,..,9, 10):

Sollte der Würfel eine der Zahlen zwischen 2 und 10 anzeigen, dann wird nicht überprüft, ob Sie in Ihrer Steuererklärungsentscheidung $\mathrm{Ihr}$ Bruttoeinkommen vollständig angezeigt haben. Ihre Auszahlung für diese Runde - das Nettoeinkommen - setzt sich in diesem Fall aus dem Bruttoeinkommen (Leistung während der Arbeitsaufgabe zuzüglich $5 \mathrm{ECU}$ ) abzüglich der Steuerzahlung zusammen. Dabei ist die Steuerzahlung der in der Steuererklärung angegebene Betrag multipliziert mit dem geltenden Steuersatz. Also:

$\rightarrow \quad$ Nettoeinkommen $=$ Bruttoeinkommen $-($ gemeldeter Betrag*Steuersatz $)$

b) Der Würfel zeigt die Zahl 1:

Sollte der Würfel die Zahl 1 anzeigen, dann wird überprüft, ob Sie in der Steuererklärung Ihr vollständiges Bruttoeinkommen angegeben haben. Abhängig von Ihrer vorher getroffenen Steuererklärungsentscheidung, gibt es in diesem Fall für Ihr Nettoeinkommen zwei Möglichkeiten: 
- Ist der von Ihnen in der Steuererklärung angegebene Betrag gleich dem wahren Bruttoeinkommen, dann setzt sich Ihr Nettoeinkommen aus dem Bruttoeinkommen minus der wahren Steuerschuld zusammen. Also:

$\rightarrow$ Nettoeinkommen $=$ Bruttoeinkommen $-($ Bruttoeinkommen*Steuersatz $)$

- Ist der von Ihnen in der Steuererklärung angegebene Betrag niedriger als das wahre Bruttoeinkommen, dann müssen Sie die volle Steuerzahlung basierend auf Ihrem echten Bruttoeinkommen zahlen und außerdem fällt eine Strafe an. Diese Strafe errechnet sich durch die Differenz zwischen ihrem echten Bruttoeinkommen und dem von Ihnen angegebenen Betrag multipliziert mit dem geltenden Steuersatz. Also:

$\rightarrow$ Nettoeinkommen $=$ Bruttoeinkommen - (Bruttoeinkommen*Steuersatz) [(Bruttoeinkommen - gemeldeter Betrag)* Steuersatz]

Dem Experimentleiter, der mit dem Würfel an Ihren Platz kommt, ist es selbstverständlich nicht möglich, einzusehen, ob Sie Ihr Bruttoeinkommen in voller Höhe angegeben haben oder nicht.

\section{Schlussbemerkungen}

Nach dem Ablauf aller 11 Runden - eine Übungsrunde plus 10 Auszahlungsrunden - ist das Experiment beendet. Einer der Experimentleiter wird an Ihren Platz kommen und sie werfen erneut einen 10-seitigen Würfel. Der Würfelwurf bestimmt nun, auf Basis welcher der 10 Auszahlungsrunden Sie bezahlt werden. Zeigt der Würfel beispielsweise „2“ an, dann besteht die in bar an Sie ausgegebene Auszahlung aus dem Nettoeinkommen, das Sie in der zweiten Auszahlungsrunde erzielt haben. Hinzu kommt die Pauschale von 2,50 Euro. Außerdem erscheint im Anschluss an das Experiment ein Fragebogen auf dem Bildschirm, den Sie bitte ausfüllen, während die Auszahlungen vorbereitet werden. Alle dort angegebenen Informationen, sowie alle während dieses Experiments erhobenen Daten, werden selbstverständlich anonymisiert und ausschließlich für wissenschaftliche Zwecke verwendet. Nachdem Sie den Fragebogen ausgefüllt haben, warten Sie bitte an Ihrem Platz bis Ihre Platznummer aufgerufen wird und Sie nach vorne kommen können, um sich Ihre Auszahlung abzuholen. 


\section{Instruktionen (Control Group)}

Herzlich willkommen und vielen Dank für Ihre Teilnahme an unserem Experiment. Bitte kommunizieren Sie ab sofort und bis zum Ende des Experimentes nicht mehr mit anderen Teilnehmern. Sollten Sie sich nicht an diese Regel halten, müssen wir Sie von dem Experiment ausschließen.

Wir bitten Sie, die Instruktionen sehr aufmerksam zu lesen. Wenn Sie nach dem Lesen oder während des Experimentes noch Fragen haben, heben Sie bitte Ihre Hand. Einer der Experimentleiter wird dann zu Ihnen kommen und Ihre Frage persönlich beantworten. Ihre Auszahlung und Ihre Entscheidungen werden vertraulich behandelt. Keiner der anderen Teilnehmer erfährt während oder nach dem Experiment, welche Entscheidungen Sie getroffen haben oder wie hoch Ihre Auszahlung war.

Sie können in diesem Experiment Geld verdienen. Wie viel Sie verdienen, hängt von Ihren Entscheidungen $a b$. Ihre Auszahlungen werden im Laufe des Experimentes in virtuellen Geldeinheiten, den Experimental Currency Units (ECU), gerechnet. 1 ECU entspricht 0,10 Euro. Ihre Auszahlung wird nach dem Ende des Experimentes in Euro umgerechnet und in bar an Sie ausgezahlt. Zusätzlich erhalten Sie für Ihr Erscheinen eine Zahlung in Höhe von 2,50 Euro.

\section{$\underline{\text { Das Experiment }}$}

\section{Übersicht}

Das Experiment besteht aus 11 Runden. In jeder Runde werden Sie eine Arbeitsaufgabe erledigen und dafür abhängig von Ihrer Leistung Geldeinheiten erhalten. Die von Ihnen verdienten Geldeinheiten aus der Arbeitsaufgabe sind zu versteuern.

\section{Auszahlung}

Die erste der 11 Runden gilt als Übungsrunde, in der Sie kein Geld verdienen können. In den 10 darauffolgenden Auszahlungsrunden können Sie Geld verdienen. Alle Runden sind völlig unabhängig voneinander, außerdem hängt Ihre Auszahlung in keiner Weise von den Entscheidungen oder Leistungen anderer Experimentteilnehmer ab. Die Auszahlung, die am Ende an Sie geleistet wird, besteht nicht aus der Summe Ihrer Nettoeinnahmen aus allen 10 Auszahlungsrunden, sondern es wird im Anschluss an das Experiment zufällig eine Runde ausgewählt, die Ihre Bezahlung bestimmt. Praktisch heißt das, dass Sie nach dem Ende aller Runden einen 10-seitigen Würfel werfen werden. Die Zahl, die der Würfel anzeigt, bestimmt die Runde, auf deren Basis Sie bezahlt werden.

\section{Ablauf einer Runde}


In jeder Runde wird Ihnen zunächst der in dieser Runde geltende Steuersatz angezeigt. Dieser Steuersatz kann, muss aber nicht, von Runde zu Runde variieren. Im nächsten Schritt absolvieren Sie am Computerbildschirm eine Arbeitsaufgabe. Nach dem Absolvieren dieser Arbeitsaufgabe werden Ihnen Ihr Bruttoeinkommen, der geltende Steuersatz und das daraus berechnete Nettoeinkommen dieser Runde angezeigt. Ihr Bruttoeinkommen basiert auf Ihrer Leistung in der Arbeitsaufgabe zuzüglich eines fixen Betrags von 5 ECU. In jeder Runde gilt für alle Teilnehmer derselbe Steuersatz. Alle von Ihnen geleisteten Steuerzahlungen werden an das Deutsche Rote Kreuz gespendet. Einzelheiten zu der Arbeitsaufgabe und der Berechnung des Nettoeinkommens sind weiter unten beschrieben.

$\rightarrow$ Zusammengefasst läuft jede der 11 Runden des Experiments wie folgt ab:

1. Information über geltenden Steuersatz

2. Absolvieren der Arbeitsaufgabe

3. Information über erwirtschaftetes Bruttoeinkommen

4. Berechnung des entsprechenden Nettoeinkommens für diese Runde

\section{Die Arbeitsaufgabe}

Am Anfang einer jeden Runde erfahren Sie zunächst den für diese Runde geltenden Steuersatz. Danach erledigen Sie an dem vor Ihnen stehenden Bildschirm eine Arbeitsaufgabe mit Hilfe der Computermaus. In jeder Runde wird die Arbeitsaufgabe genau 120 Sekunden andauern. Während der Arbeitsaufgabe erscheint ein Bildschirm, auf dem 48 sogenannte Schieber zu sehen sind. Jeder Schieber ist zunächst bei der Position „, ““ (Null) positioniert und kann von Ihnen verschoben werden. Sie können den Schieber auf jede ganze Zahl zwischen „0“ und „100“ verschieben, indem Sie den Schieber mit der Maus anklicken und die Maus bewegen. Rechts neben dem Schieber wird die aktuelle Position angezeigt. Sie können jeden Schieber so oft verschieben, wie Sie möchten. Sie erhalten für jeden Schieber, den Sie innerhalb der 120 Sekunden exakt an der Nummer „50“ positionieren 6 ECU. Oben in der Mitte können Sie während der 120 Sekunden immer ablesen, wie viele Schieber Sie aktuell bei „50“ positioniert haben.

\section{Berechnung des Nettoeinkommens}

Nachdem Sie die Arbeitsaufgabe erledigt haben, wird Ihnen Ihr Bruttoeinkommen der jeweiligen Runde angezeigt. Dieses errechnet sich aus der Anzahl der korrekt auf „50“ verschobenen Schieber zuzüglich eines fixen Betrags von 5 ECU. Dieses Bruttoeinkommen muss mit dem in dieser Runde geltenden Steuersatz versteuert werden. Ihr Nettoeinkommen für diese Runde setzt sich also aus dem Bruttoeinkommen abzüglich einer Steuerzahlung zusammen. Dabei ist die Steuerzahlung das Bruttoeinkommen multipliziert mit dem geltenden Steuersatz. Also:

$\rightarrow$ Nettoeinkommen $=$ Bruttoeinkommen $-($ Bruttoeinkommen $*$ Steuersatz $)$ 


\section{Schlussbemerkungen}

Nach dem Ablauf aller 11 Runden - eine Übungsrunde plus 10 Auszahlungsrunden - ist das Experiment beendet. Einer der Experimentleiter wird an Ihren Platz kommen und sie werfen einen 10seitigen Würfel. Der Würfelwurf bestimmt nun, auf Basis welcher der 10 Auszahlungsrunden Sie bezahlt werden. Zeigt der Würfel beispielsweise „2“ an, dann besteht die in bar an Sie ausgegebene Auszahlung aus dem Nettoeinkommen, das Sie in der zweiten Auszahlungsrunde erzielt haben. Hinzu kommt die Pauschale von 2,50 Euro. Außerdem erscheint im Anschluss an das Experiment ein Fragebogen auf dem Bildschirm, den Sie bitte ausfüllen, während die Auszahlungen vorbereitet werden. Alle dort angegebenen Informationen, sowie alle während dieses Experiments erhobenen Daten, werden selbstverständlich anonymisiert und ausschließlich für wissenschaftliche Zwecke verwendet. Nachdem Sie den Fragebogen ausgefüllt haben, warten Sie bitte an Ihrem Platz bis Ihre Platznummer aufgerufen wird und Sie nach vorne kommen können, um sich Ihre Auszahlung abzuholen. 


\section{References}

Aaberge, R. and U. Colombino (2006). Designing optimal taxes with a microeconometric model of household labour supply. IZA Discussion Paper No. 2468.

Allingham, M. G. and A. Sandmo (1972). Income tax evasion: A theoretical analysis. Journal of Public Economics 1(3-4), 323 - 338.

Alm, J. (2012). Measuring, explaining, and controlling tax evasion: lessons from theory, experiments, and field studies. International Tax and Public Finance $19(1), 54-77$.

Alm, J., K. M. Bloomquist, and M. McKee (2011). Comparing student and nonstudent reporting behavior in tax compliance experiments. In A. Plumley (Ed.), IRS Research Bulletin (Publication 1500), pp. 93 - 99. Washington D.C.: International Revenue Service.

Alm, J. and K. Finlay (2012). Who benefits from tax evasion? Tulane University Working Papers 1214.

Alm, J., B. Jackson, and M. McKee (1992). Institutional uncertainty and taxpayer compliance. American Economic Review 82(4), 1018-1026.

Alm, J., B. R. Jackson, and M. McKee (2009). Getting the word out: Enforcement information dissemination and compliance behavior. Journal of Public Economics 93(3-4), $392-402$.

Andreoni, J., B. Erard, and J. Feinstein (1998). Tax compliance. Journal of Economic Literature 36(2), 818 - 860.

Bargain, O., K. Orsini, and A. Peichl (2012). Comparing labor supply elasticities in Europe and the US: New results. IZA Discussion Papers 6735.

Bastani, S. and H. Selin (2011). Bunching and non-bunching at kink points of the swedish tax schedule. Working paper Series, Center for Fiscal Studies, Uppsala University, Department of Economics.

Bertrand, M., E. Duflo, and S. Mullainathan (2004). How much should we trust differences-in-differences estimates? Quarterly Journal of Economics 119(1), 249-275.

Blumkin, T., B. J. Ruffle, and Y. Ganun (2012). Are income and consumption taxes ever really equivalent? Evidence from a real-effort experiment. European Economic Review. Forthcoming.

Burns, S. K. and J. P. Ziliak (2012). Identifying the elasticity of taxable income. mimeo, University of Kenntucky. 
Cettolin, E. and A. Riedl (2011). Fairness and uncertainty. mimeo, Maastricht University.

Charness, G. and P. Kuhn (2011). Lab labor: What can labor economists learn from the lab? In O. Ashenfelter and D. Card (Eds.), Handbook of Labor Economics Vol 4A, pp. 229-330. Amsterdam: North Holland.

Chetty, R., J. N. Friedman, and E. Saez (2012). Using differences in knowledge across neighborhoods to uncover the impacts of the EITC on earnings. NBER Working Paper No. 18232.

Chetty, R., A. Looney, and K. Kroft (2009). Salience and taxation: Theory and evidence. American Economic Review 99(4), 1145-1177.

Collins, J., D. Murphy, and D. Plumlee (1992). The taxpayer's dilemma: How hard to work and what to report? Advances in Taxation 4, 31-53.

Cowell, F. A. (1985). Tax evasion with labour income. Journal of Public Economics 26(1), 19-34.

Dickinson, D. L. (1999). An experimental examination of labor supply and work intensities. Journal of Labor Economics 17(4), 638 - 670.

Djawadi, B. M. and R. Fahr (2012). The impact of tax knowledge and budget spending influence on tax compliance. mimeo, University of Paderborn.

Doerrenberg, P., D. R. Duncan, C. Fuest, and A. Peichl (2012). Nice guys finish last: Are people with higher tax morale taxed more heavily? CESifo working paper series no. 3858 .

Doerrenberg, P. and A. Peichl (2011). Progressive taxation and tax morale. Public Choice. Forthcoming.

Duncan, D. and K. Sabirianova Peter (2010). Does labour supply respond to a flat tax? The Economics of Transition 18(2), 365-404.

Eckel, C. C. and P. J. Grossman (1996). Altruism in anonymous dictator games. Games and Economic Behavior 16(2), 181 - 191.

Efron, B. and R. J. Tibshirani (1994). An Introduction to the Bootstrap (Chapman $\&$ Hall/CRC Monographs on Statistics $\&$ Applied Probability). New York: Chapman and Hall.

Falk, A. and E. Fehr (2003). Why labour market experiments? Labour Economics 10(4), 399-406.

Falk, A. and J. J. Heckman (2009). Lab experiments are a major source of knowledge in the social sciences. Science 326 (5952), 535-538. 
Falk, A., S. Meier, and C. Zehnder (2012). Do lab experiments misrepresent social preferences? The case of self-selected student samples. Journal of the European Economic Association. Forthcoming.

Feldstein, M. (1995). The effect of marginal tax rates on taxable income: A panel study of the 1986 tax reform act. Journal of Political Economy 103(3), 551-72.

Finkelstein, A. (2009). E-ztax: Tax salience and tax rates. Quarterly Journal of Economics 124(3), 969-1010.

Fischbacher, U. (2007). z-tree: Zurich toolbox for ready-made economic experiments. Experimental Economics 10(2), 171-178.

Fochman, M. and J. Weimann (2011). The effects of tax salience and tax experience on individual work efforts in a framed field experiment. FEMM Working Paper 20.

Fochman, M., J. Weimann, K. Blaufus, J. Hundsdoerfer, and D. Kiesewetter (2012). Net wage illusion in a real effort experiment. Scandinavian Journal of Economics. Forthcoming.

Fortin, B., G. Lacroix, and M.-C. Villeval (2007). Tax evasion and social interactions. Journal of Public Economics 91(11-12), 2089-2112.

Frederiksen, A., E. K. Graversen, and N. Smith (2005). Tax evasion and work in the underground sector. Labour Economics 12(5), 613-628.

Gill, D. and V. Prowse (2011). A novel computerized real effort task based on sliders. IZA Discussion Paper No. 5801.

Gill, D. and V. Prowse (2012). A structural analysis of disappointment aversion in a real effort competition. American Economic Review 102(1), 469-503.

Gill, D., V. Prowse, and M. Vlassopoulos (2012). Cheating in the workplace: An experimental study of the impact of bonuses and productivity. IZA Discussion Papers 6725.

Gill, D. and V. L. Prowse (2010). Gender differences and dynamics in competition: The role of luck. IZA Discussion Papers 5022.

Graetz, M. J., J. F. Reinganum, and L. L. Wilde (1986). The tax compliance game: Toward an interactive theory of law enforcement. Journal of Law, Economics and Organization 2(1), 1-32.

Greiner, B. (2004). An online recruitment system for economic experiments. In K. Kremer and V. Macho (Eds.), Forschung und wissenschaftliches Rechnen 2003. GWDG Bericht 63, pp. 79-93. Goettingen: Ges. fi $; \frac{1}{2} \mathrm{r}$ Wiss. Datenverarbeitung. 
Hammermann, A., A. Mohnen, and P. Nieken (2012). Whom to choose as a team mate? A lab experiment about in-group favouritism. IZA Discussion Papers 6286 .

Heim, B. T. (2009). The effect of recent tax changes on taxable income: Evidence from a new panel of tax returns. Journal of Policy Analysis and Management 28(1), 147-163.

Heim, B. T. (2010). The responsiveness of self-employment income to tax rate changes. Labour Economics 17(6), 940 - 950.

Keane, M. P. (2011). Labor supply and taxes: A survey. Journal of Economic Literature 49(4), 961-1075.

Kleven, H. J., M. B. Knudsen, C. T. Kreiner, S. Pedersen, and E. Saez (2011). Unwilling or unable to cheat? Evidence from a tax audit experiment in denmark. Econometrica 79(3), 651-692.

Koenig, H., F. Laisney, M. Lechner, and W. Pohlmeier (1995). Tax illusion and labour supply of married women: Evidence from German data. Kyklos 48(3), 347-368.

Kopczuk, W. (2005). Tax bases, tax rates and the elasticity of reported income. Journal of Public Economics 89(11-12), 2093-2119.

Lemieux, T., B. Fortin, and P. Frechette (1994). The effect of taxes on labor supply in the underground economy. American Economic Review 84(1), 231-54.

Levitt, S. D. and J. A. List (2007). What do laboratory experiments measuring social preferences reveal about the real world? The Journal of Economic Perspectives 21 (2), pp. 153-174.

Mann, H. B. and D. R. Whitney (1947). On a test whether one of two random variables is stochastically larger than the other. Annals of Mathematical Statistics 18, 50-60.

Minkov, M. (2012). World values survey. In G. Ritzer (Ed.), The Wiley-Blackwell Encyclopedia of Globalization. Oxford: Blackwell Publishing Ltd.

Pencavel, J. H. (1979). A note on income tax evasion, labor supply, and nonlinear tax schedules. Journal of Public Economics 12(1), 115 - 124.

Piketty, T., E. Saez, and S. Stantcheva (2011). Optimal taxation of top labor incomes: A tale of three elasticities. Technical Report 17616.

Riener, G. and S. Wiederhold (2011). On social identity, subjective expectations, and the costs of control. Jena Economic Research Papers 2011-035. 
Roed, K. and S. Strom (2002). Progressive taxes and the labour market: Is the trade-off between equality and efficiency inevitable? Journal of Economic Surveys 16(1), 77-110.

Rosen, H. S. (1976a). Tax illusion and the labor supply of married women. The Review of Economics and Statistics 58(2), 167-172.

Rosen, H. S. (1976b). Taxes in a labor supply model with joint wage-hours determination. Econometrica 44(3), 485-507.

Saez, E. (2010). Do taxpayers bunch at kink points? American Economic Journal: Economic Policy 2(3), 180-212.

Saez, E., J. Slemrod, and S. H. Giertz (2012). The elasticity of taxable income with respect to marginal tax rates: A critical review. Journal of Economic Literature 50(1), 3-50.

Sandmo, A. (1981). Income tax evasion, labour supply, and the equity-efficiency tradeoff. Journal of Public Economics 16(3), 265 - 288.

Sausgruber, R. and J.-R. Tyran (2005). Testing the mill hypothesis of fiscal illusion. Public Choice 122(1), 39-68.

Slemrod, J. (1992). Do taxes matter? Lessons from the 1980's. American Economic Review. Papers and Proceedings 82(2), 250 - 256.

Slemrod, J. (1994). On the high-income laffer curve. In J. Slemrod (Ed.), Tax Progressivity and Income Inequality, pp. 177-210. Cambridge, New York and Melbourne: Cambridge University Press.

Slemrod, J. (2001). A general model of the behavioral response to taxation. International Tax and Public Finance 8, 119-128.

Slemrod, J. (2007). Cheating ourselves: The economics of tax evasion. Journal of Economic Perspectives 21(1), 25 - 48.

Slemrod, J. and W. Kopczuk (2002). The optimal elasticity of taxable income. Journal of Public Economics 84(1), 91-112.

Slemrod, J. and C. Weber (2012). Evidence of the invisible: toward a credibility revolution in the empirical analysis of tax evasion and the informal economy. International Tax and Public Finance 19, 25-53.

Slonim, R. and A. E. Roth (1998). Learning in high stakes ultimatum games: An experiment in the slovak republic. Econometrica $66(3)$.

Torgler, B. (2002). Speaking to theorists and searching for facts: Tax morale and tax compliance in experiments. Journal of Economic Surveys 16(5), 657 683. 
Torgler, B. (2007). Tax Compliance and Tax Morale: A Theoretical and Empirical Analysis. Cheltenham, UK: Edward Elgar.

Tversky, A. and D. Kahneman (1974). Judgment under uncertainty: Heuristics and biases. Science 185, 1124-1131.

Wilcoxon, F. (1945). Individual comparisons by ranking methods. Biometrics 1, 80-83.

Wooldridge, J. M. (2010). Econometric Analysis of Cross Section and Panel Data (2 ed.). The MIT Press. 